\title{
1 Geophysical Constraints on the Antarctic Sea Ice Cover
}

2 S. V. Nghiem ${ }^{\mathrm{a}, \mathrm{b}^{*}}$, I. G. Rigor ${ }^{\mathrm{c}}$, P. Clemente-Colón ${ }^{\mathrm{d}}$, G. Neumann ${ }^{\mathrm{a}}$, and P. P. Li ${ }^{\mathrm{a}}$

3 a Jet Propulsion Laboratory, California Institute of Technology, 4500 Oak Grove Drive, MS 300-

4 235, Pasadena, California 91109, USA. E-mail Son.V.Nghiem@jpl.nasa.gov

5 bJoint Institute for Regional Earth System Science and Engineering, University of California, Los

6 Angeles, California 90095, USA

7 'Applied Physics Laboratory, University of Washington, 1013 NE 40th Street, Box 355640,

8 Seattle, Washington 98105, USA

9 dU.S. National/Naval Ice Center, NOAA Satellite Operations Facility, 4251 Suitland Road,

10 Washington District of Columbia 20395, USA

11 Key words: Antarctic sea ice, passive and active microwave remote sensing, frontal ice zone,

12 wind patterns, Antarctic Circumpolar Current front, GEBCO bathymetry.

\section{Abstract}

14 The contrast between the slight increase of Antarctic sea ice and the drastic reduction of Arctic

15 sea ice since the 1970s has been a conundrum to be resolved. Sea ice trajectory tracking with

16 satellite scatterometer data in 2008 shows that ice that forms around Antarctica is pushed

17 offshore by katabatic winds influenced by the continental topography. The ice trajectories reveal

18 that sea ice, formed earlier in the ice growth season, drifts northward away from the Antarctic

19 continent forming a circumpolar frontal ice zone (FIZ) behind the ice edge. The FIZ thereby

20 consists of sea ice that becomes rougher due to a longer exposure to wind and wave actions, and

21 thicker over time by more ice growth and greater snow accumulation.

\footnotetext{
* Corresponding author
} 
In the Antarctic circumpolar sea ice zone adjacent to the sea ice edge, satellite data in 1999-

232009 exhibit a band of strong radar backscatter, which is consistent with the signature of older,

24 thicker, and rougher sea ice with more snow in the FIZ. This sea ice band, as wide as $1000 \mathrm{~km}$,

25 serves as a 'Great Shield,' encapsulating and protecting younger and thinner ice in the internal

26 ice pack. In the young and thin ice region behind the FIZ, ice can grow rapidly as winds

27 continue opening interior areas thereby creating effective "ice factories." In addition, ridging can

28 enhance ice thickness by convergence toward the circumpolar FIZ that is recirculated by

29 westerly winds and currents. During the growth season, the FIZ advances until reaching lower-

30 latitude warm waters at a boundary determined by the southern Antarctic Circumpolar Current

31 front that is constrained by seafloor features. These persistent topographical and bathymetric

32 geological factors help sustain the Antarctic sea ice cover. As such, the behavior of Antarctic sea

33 ice is not a paradox as some have suggested, but instead is consistent with the geophysical

34 characteristics in the southern polar region that starkly contrast to those in the Arctic.

\section{1. Introduction}

36 The extent of Antarctic sea ice has increased slightly while Arctic sea ice has diminished

37 drastically in recent decades (IPCC, 2013). This has been cited as a challenging paradox (Walsh,

38 2009) for which a number of explanations have been suggested, and the inconsistency between

39 simulated and observed changes in Antarctic sea ice remains to be explained (Gagné et al.,

40 2015). Stratospheric ozone depletion may affect atmospheric circulation patterns such as the

41 Southern Annular Mode (SAM), limiting sea surface temperature (SST) change and sustaining

42 the Antarctic sea ice cover (Marshall, 2003; Gillett \& Thompson, 2003; Son et al., 2010).

43 However, Sigmond and Fyfe (2010) question the efficacy of ozone depletion on sea ice change 
44 and strongly suggest that processes not linked to stratospheric ozone depletion must be invoked

45 to explain the observation of the small increase in the Antarctic sea ice extent.

46 Meltwater from Antarctic ice shelves (Rignot et al., 2013) accumulates in a cool and fresh

47 surface layer that cushions the surface ocean from warmer deeper waters leading to an expansion

48 of Antarctic sea ice (Bintanja et al., 2013). The reduction of salinity and density in this near-

49 surface layer may weaken the convective mixing of cold surface water with the underlying

50 warmer water, and thus sustain Antarctic sea ice (Manabe et al., 1991). Moreover, a decrease in

51 sea ice growth may reduce salt rejection and upper-ocean density to enhance thermohaline

52 stratification which suppresses convective overturning, decreases upward heat transport, and thus

53 maintains Antarctic sea ice production (Zhang, 2007). Winds also affect Antarctic sea ice trends

54 (Holland, 2014), and model simulations indicate wind intensification may increase ice

55 production by ridging (Zhang, 2013). As a frozen continent, Antarctica lacks heat sources such

56 as warm river waters, breaking through landfast sea ice held by the regional bathymetry, can

57 effectively melt sea ice as occurs in the Arctic (Nghiem et al., 2014).

58 In contrast to past studies, this paper presents satellite observations that reveal the formation

59 of a circumpolar frontal ice zone of older, rougher, and thicker sea ice, referred here as a 'Great

60 Shield' zone (GSZ) that in turn protects the Antarctic interior sea ice pack from melting. Also

61 examined are persistent factors that sustain an effective ice growth while maintaining the

62 Antarctic sea ice cover (i.e., decadal trend with a low rate of change of the seasonal maximum

63 extent of the overall Antarctic sea ice cover, typically in late September). The focus here is on

64 the growth season of Antarctic sea ice until its extent reaches the seasonal maximum in

65 September, when the sea ice surface is under freezing conditions without significant melt to

66 obscure satellite signatures of sea ice. 


\section{Antarctic Sea Ice Change}

68 Antarctic sea ice extent (SIE) retreats to a minimum of $3.1 \times 10^{6} \mathrm{~km}^{2}$ in February, which is

69 just $16.8 \%$ of the maximum extent of $18.5 \times 10^{6} \mathrm{~km}^{2}$ in September as observed from multi-

70 decadal satellite data (1979-2013) (Parkinson, 2014). Overall, the Antarctic SIE has a relatively

71 low rate of change since the late 1970 s with a slight increase that has not been nearly as large as

72 the decreasing trend of the SIE in the Arctic and not as widespread geographically (Parkinson,

73 2014). There are also regional differences such as the decrease of sea ice with a shortened ice

74 season in the Bellingshausen Sea region (see Fig.1 for geographical names of seas and locations

75 around Antarctica) in contrast to the late retreat and early advance in the western Ross Sea region

76 (Stammerjohn et al., 2012). Successive Antarctic SIE maximum records in 2012, 2013, and 2014

77 from satellite observations (Parkinson, 2014; Reid and Massom, 2015), in contrast to record low

78 values of Arctic SIE in March to early June 2015 (SPIN, 2015), have further accentuated the

79 polar sea ice differences.

80 A reliable estimate of the Antarctic snow and sea ice thickness is still elusive (Giles et al.,

81 2008), while there have been some seasonal estimates from Ice, Cloud, and land Elevation

82 Satellite (ICESat) data collected along lines on sea ice surface in different regions at different

83 times in different years (Kurtz \& Markus, 2012) with a large range of uncertainty between $20 \%$ -

$8480 \%$ (Kern \& Spreen, 2015). Such fundamental information is crucial for predictive models to

85 attribute observed changes and to assess various impacts (Maksym et al., 2012). Antarctic sea ice

86 properties and growth processes can be quite different from those in the Arctic. With strong

87 wind and wave interactions, Antarctic sea ice is not necessarily limited to thermodynamic growth

88 under quiescent conditions as its thickness can be significantly increased from rafting and

89 ridging (Lewis et al., 2011; Massom et al., 2008) and from heavy snow loading, flooding, and 

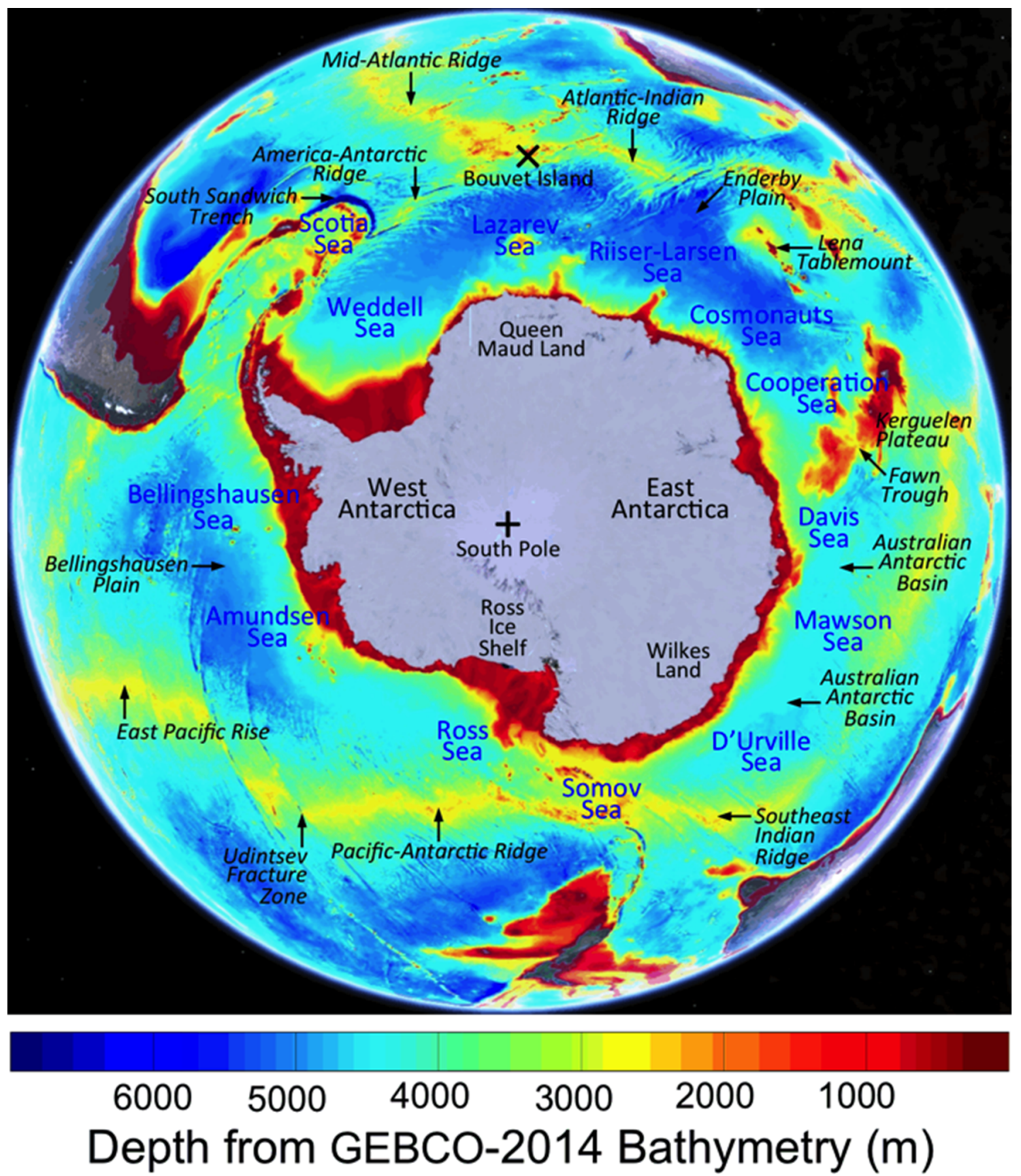

Fig. 1. Names of places on a map of Antarctic land and ocean together with the GEBCO-2014 bathymetry (http://www.gebco.net/data_and_products/gridded_bathymetry_data/).

91 freezing at the top (Ackley \& Sullivan, 1994; Jeffries et al., 1997; Massom et al., 2001). During

92 the ice-growing season, besides the thermodynamic growth, the older sea ice becomes thicker

93 having more time for snow loading through aggregate accumulation and for greater roughness

94 due to a prolonged exposure to high winds and large waves. Therefore, detailed measurements 
95 of snow and ice thickness and other physical properties in various regions of Antarctic sea ice are

96 necessary to identify key dynamic and thermodynamic processes to explain Antarctic sea ice

97 change.

98 As the thickness information lacks in spatial coverage, revisit frequency, and long-term

99 record, our approach is to utilize observations of the dynamics from sea ice trajectory tracking

100 and from distribution patterns of synoptic sea ice classes from a decade of Ku-band radar data,

101 acquired in 1999-2009 by the SeaWinds scatterometer (a stable and accurate radar) aboard the

102 QuikSCAT satellite. This approach allows an immediate examination of sea ice processes within

103 the SIE from currently available data as a surrogate to the deficient information of Antarctic sea

104 ice thickness distribution.

\section{3. Tracking Sea Ice Trajectories}

106 To examine the evolution of Antarctic sea ice over the growth season (June-September), we 107 implement an algorithm using daily QuikSCAT science data at Level 1B (L1B), accurate to 0.2 $108 \mathrm{~dB}$ or $4.7 \%$ for $3 \sigma$ at $\sim 99.7 \%$ confidence level (Tsai et al., 2000), to track the dynamics and 109 formation of the different sea ice classes. The active microwave L1B scatterometer data in a 110 posting of $0.25^{\circ}$ in latitude and in longitude are provided as input to the tracking algorithm 111 developed specifically for use with the satellite scatterometer observations. These are re112 projected into polar coordinates and then interpolated to a rectangular grid with $0.1^{\circ}$ spacing 113 using a nearest neighbor scheme. An initial set of points in a $2^{\circ}$ grid on sea ice for 1 June 2008 is 114 chosen (Fig. 2a), with associated ice parcels tracked from the sequential rectangular-grid daily

115 L1B data. Year 2008 is selected for this dynamic process study as it was one of the years of 116 exceptional seasonal variability in Antarctic sea ice coverage, which was characterized by three 117 distinctive phases of SIE anomalies and substantial regional variations (Massom et al., 2009), so 

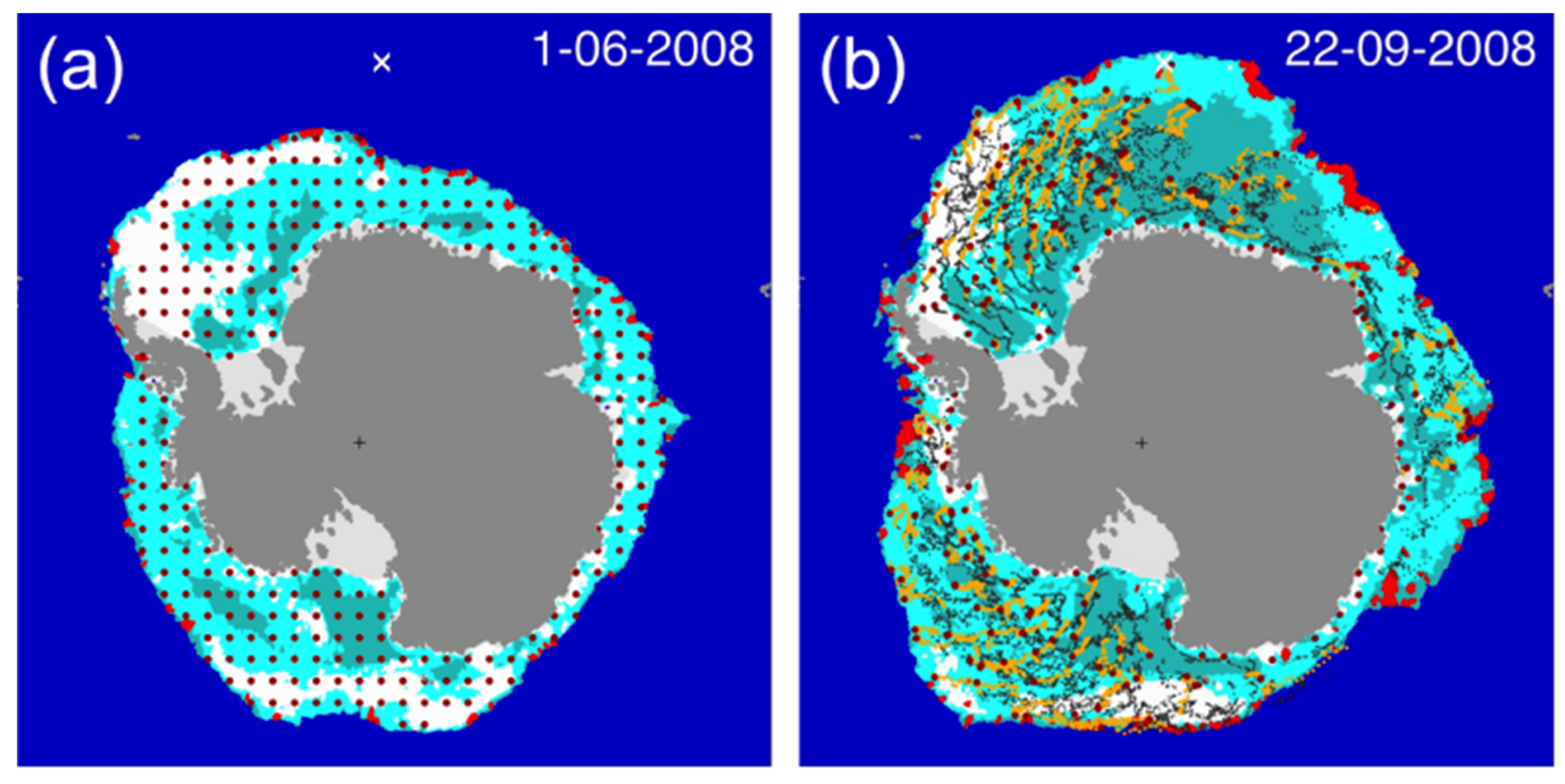

Fig. 2. Tracking of trajectories of sea ice parcels over different synoptic sea ice classes (see definitions in Section 4 and color code in Fig. 4). The left panel (a) represents the initial set of points in a $2^{\circ}$ grid on sea ice for 1 June 2008 to track the sea ice parcels associated with this set of points to track their trajectories while no new points are introduced or inserted throughout the tracking process. The right panel (b) shows the trajectories of the sea ice parcels at the end of the tracking on the equinox of 22 September 2008, tracing the entire history of the trajectory of each sea ice parcel from where it started, moved around, reached its final position. Red dots are the current positions of the trajectories on the given date with the orange trails indicating the drift of the tracks during the past 30 days and the trails consisting of small black dots completing all tracking points along the sea ice tracks since 1 June 2008. An animation of the daily sea ice trajectories is presented in Movie 1 at http://urban.jpl.nasa.gov/images/NghiemEtAl-Movie1.avi.

118 that a large range of different conditions can be included in this study. The algorithm tracks the

119 parcels by finding the maximum correlation of a $5 \times 5$ window of pixels from one day to the next

120 until September 30, 2008, or until the parcel is "melted out" as defined by its leaving the SIE.

121 The tracking algorithm uses ancillary SIE products derived from passive microwave data and

122 other satellite observations. SIE datasets are readily available from the U.S. National Ice Center

123 (NIC) and from the Integrated Climate Data Center (ICDC). The NIC SIE mask is generated

124 from detailed manual analyses of the extent of the sea ice cover using multiple active and passive

125 microwave, visible, and infrared satellite data sources, including observations with spatial

126 resolution of the order of $100 \mathrm{~m}$. NIC analysts pay particular attention during their sea ice cover 
127 analyses to the location of the ice edge because of the need to maintain domain awareness for

128 safe operations near the ice edge. The use of multisensory and high-resolution data provides for

129 a more accurate delineation of SIE than what could be generated alone from automated satellite

130 algorithms. The NIC sea ice edge position analyses have been validated with a good agreement

131 found by a comparison with ship observations (Ozsoy-Cicek et al., 2009). Antarctic SIE data for

132 this study are available from NIC for 2006-2009.

133 To supplement NIC SIE data product before 2006, the ICDC sea ice concentration (SIC) $>0$

134 is used to determine a SIE consistent with the conservative SIE definition by NIC. ICDC SIC

135 values have been computed at the French Research Institute for Exploitation of the Sea with the 136 Arctic Radiation and Turbulence Interaction Study (ARTIST) Sea Ice algorithm (Kaleschke et

137 al., 2001; Spreen et al., 2008; Kern et al., 2010) applied to brightness temperatures measured 138 with the $85 \mathrm{GHz}$ Special Sensor Microwave/Imager (SSM/I) and/or Special Sensor Microwave 139 Imager / Sounder (SSMIS) channels with a grid resolution of $12.5 \mathrm{~km}$. The results have 140 compared fairly well with ship observations and with satellite products from other algorithms 141 (Beitsch et al., 2015). The combination of the NIC and ICDC SIE is used together with 142 QuikSCAT data to obtain results over the decadal period of 1999-2009.

143 Presented in Fig. 2 are the tracking points at the start on 1 June 2008 (Fig. 2a) and the 144 trajectories as these points are traced from their initial places in the austral autumn to their 145 locations on the equinox of 22 September 2008 (Fig. 2b) when the season transitioned from the 146 austral winter to the austral spring. From the trajectories, several general characteristics of 147 Antarctic sea ice dynamics are observed. There was an advection of sea ice outward and away 148 from the coast of Antarctica, especially in the Weddell, Lazarev, Riiser-Larsen, and Cosmonauts 149 Seas. Sea ice was also pushed away outward from the Ross Ice Shelf in the Ross Sea, where a 
150 split in the ice drift eastward and westward could be identified (6 o'clock area on sea ice in Fig.

$1512 \mathrm{~b}$ ). In the sea ice zone behind the sea ice edge, the trajectories reveal a westward recirculation

152 of sea ice. Overall, the trajectories show that sea ice, which formed earlier around Antarctica in

153 June was forced toward lower latitudes in later months, thereby forming an outer zone of older

154 sea ice while vacating and thus diverging the internal sea ice where newer ice could grow 155 effectively.

156 A number of tracking points near the coast around Antarctica remained stationary, 157 consistently with their locations on landfast ice (multiple white areas next to the coast in Fig. 2b, 158 also see Movie 1 at http://urban.jpl.nasa.gov/images/NghiemEtAl-Movie1.avi). The capability to 159 track complex ice trajectories was verified with the existence of several icebergs that were 160 closely followed by the trajectories as found in the Cooperation Sea, where one of the icebergs 161 moved in an $\Omega$ loop (3 o'clock area in Movie 1). Specific details of the sea ice dynamics will be 162 presented together with the seasonal evolution of synoptic sea ice classes later in Section 6.

\section{4. Synoptic Patterns of Sea Ice Backscatter Signatures}

164 As indicated by the sea ice trajectory tracking, the early sea ice cover grown around the

165 Antarctic continent was forced outward toward lower latitudes to form an outer zone of sea ice 166 containing older and thus thicker and rougher sea ice with more snow accumulation, while the

167 internal ice is younger and thus thinner. From electromagnetic scattering physics based on the 168 first principle of Maxwell's equations for the snow-covered sea ice (Nghiem et al., 1990; 1993; 169 1995; Golden et al., 1998; Barber and Nghiem, 1999), the older, thicker, and rougher ice with 170 more snow must have backscatter higher than that of the younger ice.

171 From Antarctic field observations, QuikSCAT backscatter of sea ice has been shown by 172 Markus et al. (2011) to correlate with ICESat variability, which in turn correlates with the 
173 standard deviation of the overall snow depth and ice thickness from in-situ snow and ice

174 measurements. Toyota et al. (2011) find that the mean ice thickness of Antarctic sea ice has a

175 correlation with surface roughness that is even higher compared to that with the mean freeboard.

176 Thus, sea ice backscatter must be higher across the outer sea ice zone around the front of the SIE

177 behind the ice edge to be consistent with the physical characteristics of the older sea ice in that

178 frontal ice zone (FIZ). This needs to be investigated to verify the consistency between the

179 patterns of sea ice age from the ice tracking results and spatial patterns of sea ice backscatter

180 from observations with QuikSCAT satellite data.

181 To identify different backscatter patterns of Antarctic snow-covered sea ice, we examine its

182 radar backscatter signatures over the Southern Ocean. Fig. 3 presents QuikSCAT backscatter 183 synoptic images, together with multi-temporal plots along five different transects from the 184 Antarctic coast to the ice edge as sea ice grew from June to its peak extent in September of 2008.

185 These transects are selected to be in different regions of the Southern Ocean along these 186 longitudes: (a) $3.38^{\circ} \mathrm{E}$ in the Lazarev Sea coming across Bouvet Island at $54.43^{\circ} \mathrm{S}$, (b) $45.0^{\circ} \mathrm{E}$ in 187 the Cosmonauts Sea, (c) $176.62^{\circ} \mathrm{W}$ in the Ross Sea meridionally conjugated to the Bouvet 188 transect, (d) $135.0^{\circ} \mathrm{W}$ in the Amundsen Sea, and (e) $30.0^{\circ} \mathrm{W}$ in the Weddell Sea. Refer to Fig. 1 189 for geographical names.

190 Over the synoptic sea ice patterns and in all transects (Fig. 3), QuikSCAT satellite 191 observations reveal a special feature of Antarctic sea ice backscatter signatures with high values $192(>-15 \mathrm{~dB})$ forming a circumpolar band along the sea ice edge that encapsulates the internal ice 193 pack characterized by low backscatter. Such feature is consistent with the results from ice 194 trajectory tracking, and thereby supports the existence of the FIZ containing older sea ice that is 195 thicker and rougher with more snow accumulation. The FIZ surrounds the internal younger sea 


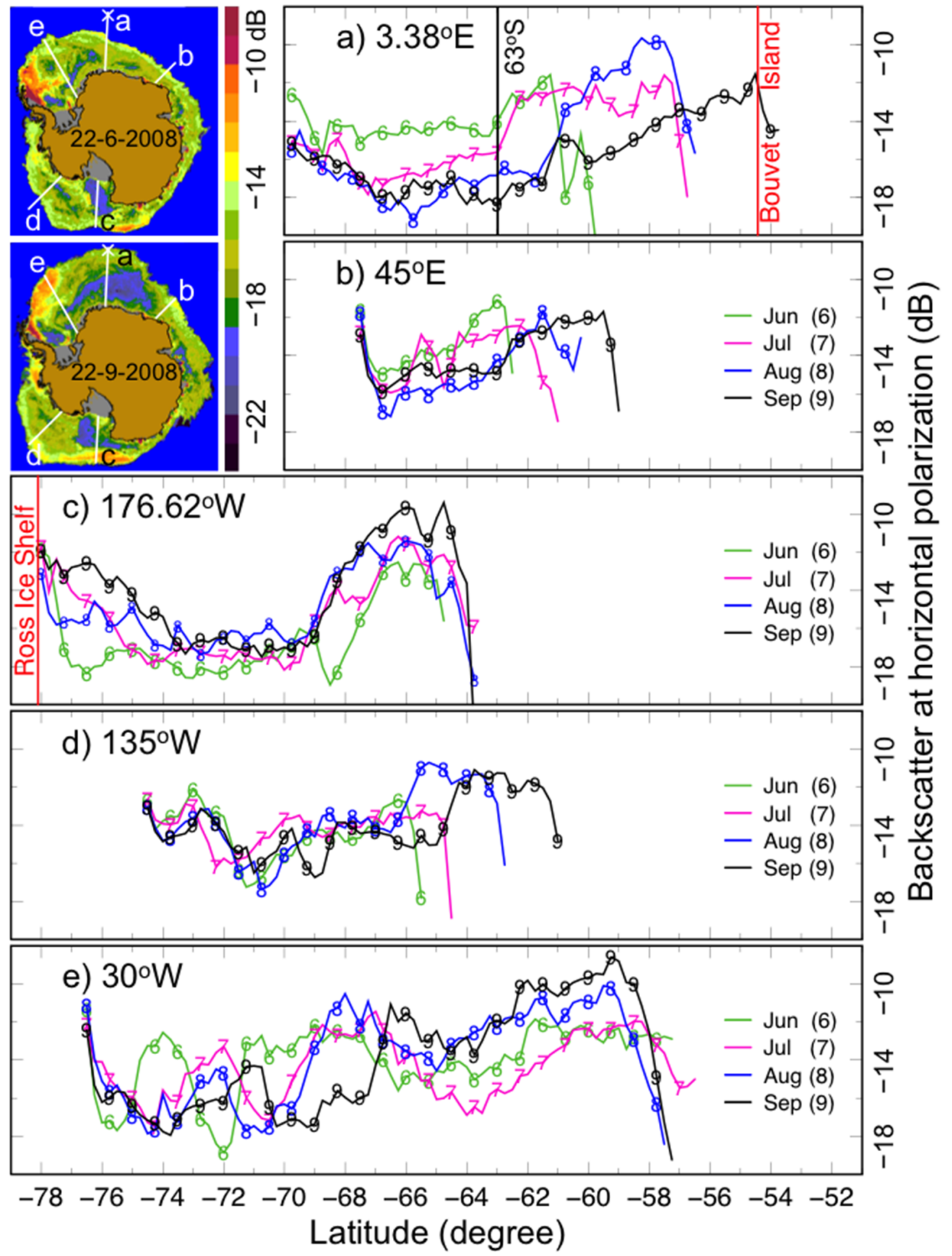

Fig. 3. Radar backscatter patterns and transect plots of Antarctic sea ice observations in 2008 by the QuikSCAT satellite scatterometer operated at the Ku-band frequency of $13.4 \mathrm{GHz}$. The top left insets are for QuikSCAT backscatter of sea ice on 22 June and 22 September 2008, where the color scale is for backscatter values, blue for ocean, grey for permanent ice, and brown for land. The backscatter plots are for (a) Transect a along $3.38^{\circ} \mathrm{E}$, (b) Transect b along $45.0^{\circ} \mathrm{E}$, (c) Transect $\mathrm{c}$ along $176.62^{\circ} \mathrm{W}$, (d) Transect d along $135.0^{\circ} \mathrm{W}$, and (e) Transect e along $30.0^{\circ} \mathrm{W}$. The plot colors are green for June, magenta for July, blue for August, and black for September. 
197 ice with a lower backscatter signature as much as 3-6 dB (equivalent to 2-4 times, converged into 198 the linear domain from the logarithmic $\mathrm{dB}$ values) less than that of the sea ice in the FIZ (Fig. 3).

199 The time-series plots in Fig. 3 present the evolution of sea ice in different Antarctic regions 200 as a function of latitude. Along Transect a (Fig. 3a) from June to July 2008, the FIZ became 201 widened as its outer edge advanced toward Bouvet Island. In August, the FIZ inner edge was 202 pushed outward and its width contracted. The FIZ continued extending farther north as it reached 203 Bouvet Island in September. As an example at latitude $63^{\circ} \mathrm{S}$ on Transect a (vertical black line in 204 Fig. 3a), backscatter was decreasing from June to September, indicating the northward passage 205 of the FIZ while the space behind remained opened and even expanded for more ice divergence, 206 thus creating new spaces where sea ice can effectively grow to form younger and thus thinner ice 207 consistently associated with lower backscatter. If the seasonal evolution of sea ice formation 208 were dominated only by thermodynamic ice growth in place, then the backscatter should have 209 been increasing along with the sea ice growth at that location. This example highlights the 210 interplay of dynamics and thermodynamics in the seasonal evolution of Antarctic sea ice.

211 The FIZ along Transect b (Fig. 3b), characterized by the high backscatter signature, gradually 212 migrated northward between June and September. In the Ross Sea, it was already established by 213 June and consistently maintained there during June-September as seen in Transect c (Fig. 3c). In 214 the Amundsen Sea along Transect d (Fig. 3d), the FIZ moved to northward with a slight decrease 215 in the peak magnitude between June and July then became significantly pronounced in August 216 and September. Along Transect e (Figure 3e) in the Weddell Sea, the FIZ was the widest with 217 the sea ice edge persisting between $57^{\circ} \mathrm{S}$ and $58^{\circ} \mathrm{S}$. Although showing variable characteristics 218 over different oceanic regions, these transect profiles capture the presence of the FIZ around 
219 Antarctica constituting a circumpolar band of sea ice (GSZ), which will be quantitatively defined

220 with synoptic sea ice classes in Section 5.

221 5. Synoptic Classes of Sea Ice

222 Here, the objective is to capture the synoptic patterns of Antarctic sea ice pertaining to

223 different classes of sea ice having different backscatter signatures corresponding to older and

224 younger sea ice with different ice thickness, roughness, and snow accumulation as presented

225 earlier in Section 4. This necessitates the development of a method for a synoptic classification

226 of Antarctic sea ice. Hence, we carry out a statistical analysis of Antarctic sea ice backscatter

227 during the sea ice growth period from June to September over the entire Southern Ocean. We

228 find that the backscatter histograms have a typical shape similar to that of the Gaussian

229 distribution with a single peak. This is in contrast to the bimodal distribution of Arctic sea ice

230 backscatter, having separate and distinctive peaks for seasonal and perennial sea ice in freezing

231 seasons, which was used in the algorithm development for Arctic sea ice classification (Nghiem

232 et al., 2006, Nghiem and Neumann, 2007). This is because Antarctic sea ice is dominated

233 primarily by first-year sea ice, rather than the coexistence of two major distinctive classes of

234 first-year (seasonal) and multi-year (perennial) ice in the Arctic (Nghiem et al., 2007).

235 Since the Antarctic sea ice backscatter $\left(\sigma_{0}\right)$ statistics are similar to the Gaussian distribution,

236 the probability density function of $\sigma_{0}$ is determined by two independent parameters: The mean

237 value $(\sigma M)$ and the standard deviation $(S T D)$, which are used here as the basis to define synoptic

238 sea ice classes. First, we identify the high backscatter range with values larger than $\sigma_{M}$ as

239 corresponding to older, rougher, and thicker sea ice with more snow in the FIZ, and the low

240 backscatter range with values smaller than $\sigma_{M}$ as pertaining to younger and thus thinner sea ice

241 with less snow. Then, an additional synoptic sea ice class with backscatter larger than one STD 
242 above $\sigma_{M}$ is identified as corresponding to the most-deformed older ice and thus likely the

243 thickest sea ice. Based on these backscatter ranges, the following synoptic sea ice classes are

244 defined: Rough older ice (RI) for $\sigma_{0}>\sigma_{M}+S T D$, older ice (OI) for $\sigma_{M}+S T D \geq \sigma_{0}>\sigma_{M}$, and

245 younger ice (YI) for $\sigma_{M} \geq \sigma_{0}$. Coincidentally, these thresholds are found to be within $0.3 \mathrm{~dB}$ of

246 those used to identify different Arctic sea ice classes (Nghiem et al., 2006, 2007). In addition, a

247 limited amount of 'permanent' ice, including ice shelves and persistent landfast ice, is routinely

248 identified and mapped around Antarctica by the NIC (NIC, 2015).

249 Per the above definition, the synoptic sea ice classes are mapped from QuikSCAT 250 backscatter data within the ancillary SIE products from NIC and ICDC that are described earlier

251 in Section 3. Patterns of the distribution of sea ice classes are presented in Fig. 4 around the

252 September equinox in 1999-2009. This is the seasonal transition time from the austral winter

253 into the spring when the Antarctic SIE is generally at or near its maximum extent in each year.

254 In all years, the Antarctic sea ice cover was encapsulated all around the ice pack by a FIZ, which

255 is now defined as the sea ice zone consisting of RI and OI classified quantitatively with $\sigma_{M}$ and

256 STD pertaining to the Gaussian statistics of sea ice $\sigma_{0}$. The outer ice edge of the FIZ can be

257 found close to the coast in regions such as in the Somov Sea, D'Urville Sea, and Mawson Sea, or

258 very far away from the coast particularly in the Lazarev Sea where the FIZ may extend all the 259 way to Bouvet Island (white cross in Fig. 4).

260 The FIZ characteristics around Antarctica are found to be quite variable over the years, 261 particularly in certain seas such as the Ross Sea when comparing 2001 and 2006 observations, or 262 the Weddell Sea when comparing 1999 and 2008 observations. The width at different locations 263 can vary by an order of magnitude from $\sim 100 \mathrm{~km}$ to $\sim 1000 \mathrm{~km}$ whereas the location of the inner 

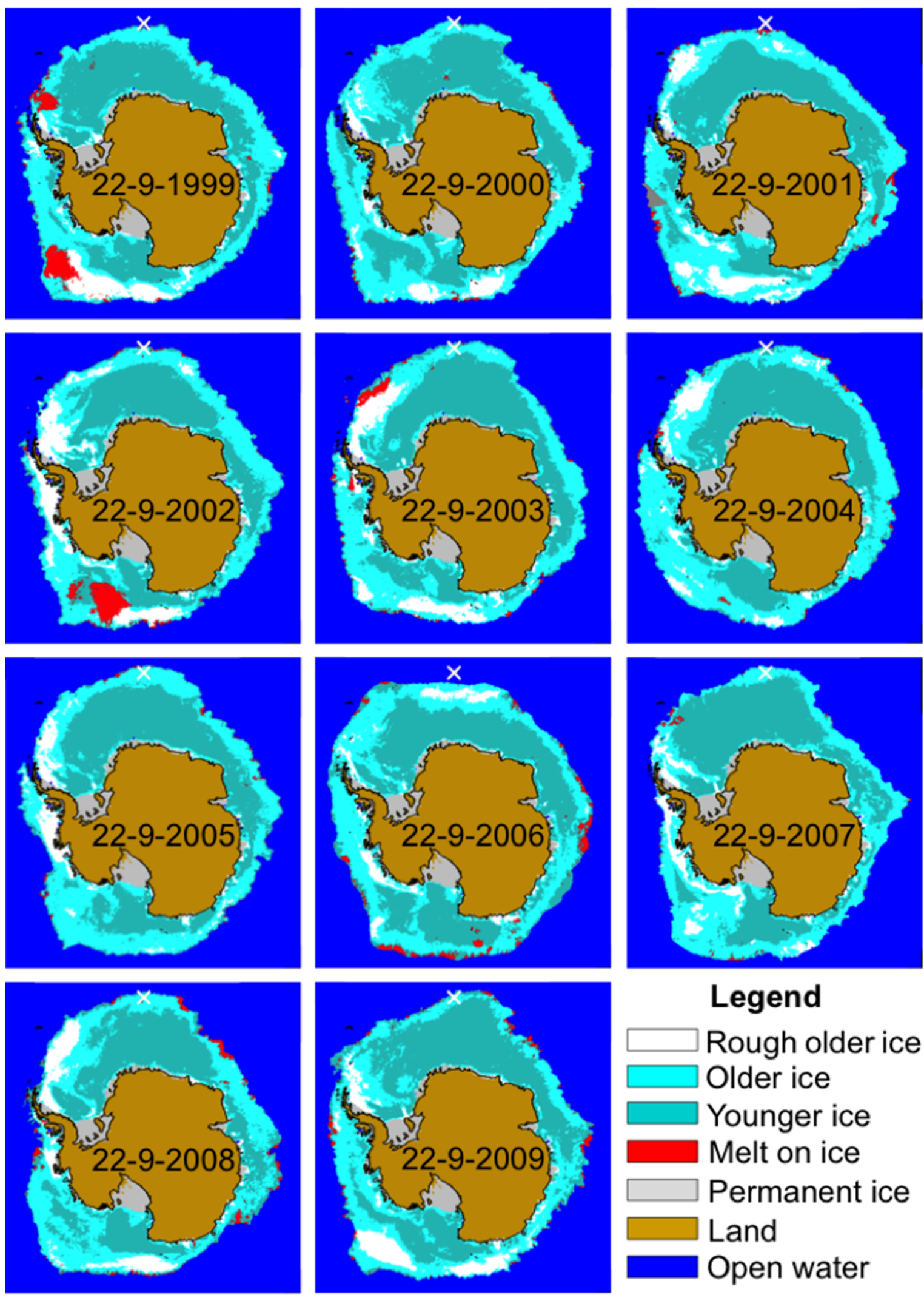

\section{Legend}

Rough older ice Older ice

$\square$ Younger ice

Melt on ice

$\square$ Permanent ice

$\square$ Land

Open water

Fig. 4. Synoptic classes of Antarctic sea ice around the September equinox in 1999-2009. The location of Bouvet Island is marked with the white cross. 
265 side of the FIZ can be very close to the Antarctic coast or more than $1000 \mathrm{~km}$ away. Table 1

266 shows quantitative examples of measurements of the FIZ widths, and the distances from its inner

267 side to the Antarctic coast along multiple transects across various seas in the Southern Ocean at

268 different seasonal times in 2008. Despite this large variability, the extensive circumpolar FIZ

269 surrounds YI in the internal ice pack in all years (Fig. 4). Formed by a combination of OI and

270 RI, it helps protect and maintain (more details later) the internal younger and thinner sea ice that

271 likely has less snow cover due to its shorter time available for the seasonal snow accumulation.

272 As such, the FIZ acts as a shield zone (GSZ) or a defensive barrier for the thinner and weaker

273 internal ice pack that continues growing as the GSZ advances toward its outermost position in

274 the austral spring as shown in the next section.

275

276

277

278

279

280

281

282

283

284

285

286

Table 1. Frontal ice zone (FIZ) distances and widths along different longitudes on 22 July, 22 August, and 22 September 2008. The FIZ distance is between the coastline (or the outer edge of Ross ice shelf) and the inner edge of FIZ. The FIZ width is between the inner and outer edges of the FIZ. The uncertainty in the FIZ distance and FIZ width is $\pm 25 \mathrm{~km}$.

\begin{tabular}{|c|c|c|c|c|c|c|}
\hline \multirow{2}{*}{ Longitude ( $\mathbf{(}^{\mathbf{}}$} & \multicolumn{3}{|c|}{ Distance (km) } & \multicolumn{3}{c|}{ Width (km) } \\
& 22 Jul & 22 Aug & 22 Sep & 22 Jul & 22 Aug & 22 Sep \\
\hline 3.38 & 885 & 1100 & 1410 & 720 & 470 & 495 \\
\hline 45.0 & 190 & 465 & 515 & 550 & 355 & 360 \\
\hline-176.62 & 1050 & 1035 & 1055 & 530 & 530 & 510 \\
\hline
\end{tabular}

\section{Seasonal Evolution of Sea Ice}

To examine the seasonal evolution of sea ice, the retrieved trajectories of sea ice parcels are overlaid on maps of sea ice classes in Fig. 5 for day 22 of June, July, August, and September 2008 covering the period from around June solstice to September equinox. By 22 June 2008 (top left, Fig. 5), a sea ice cover, containing an extensive distribution of OI and RI, was observed to have formed from close to the Antarctic coast extending to the sea ice edge with areas of YI present particularly in the Weddell, Lazarev, Riiser-Larsen, Ross, and Amundsen Seas. In those 

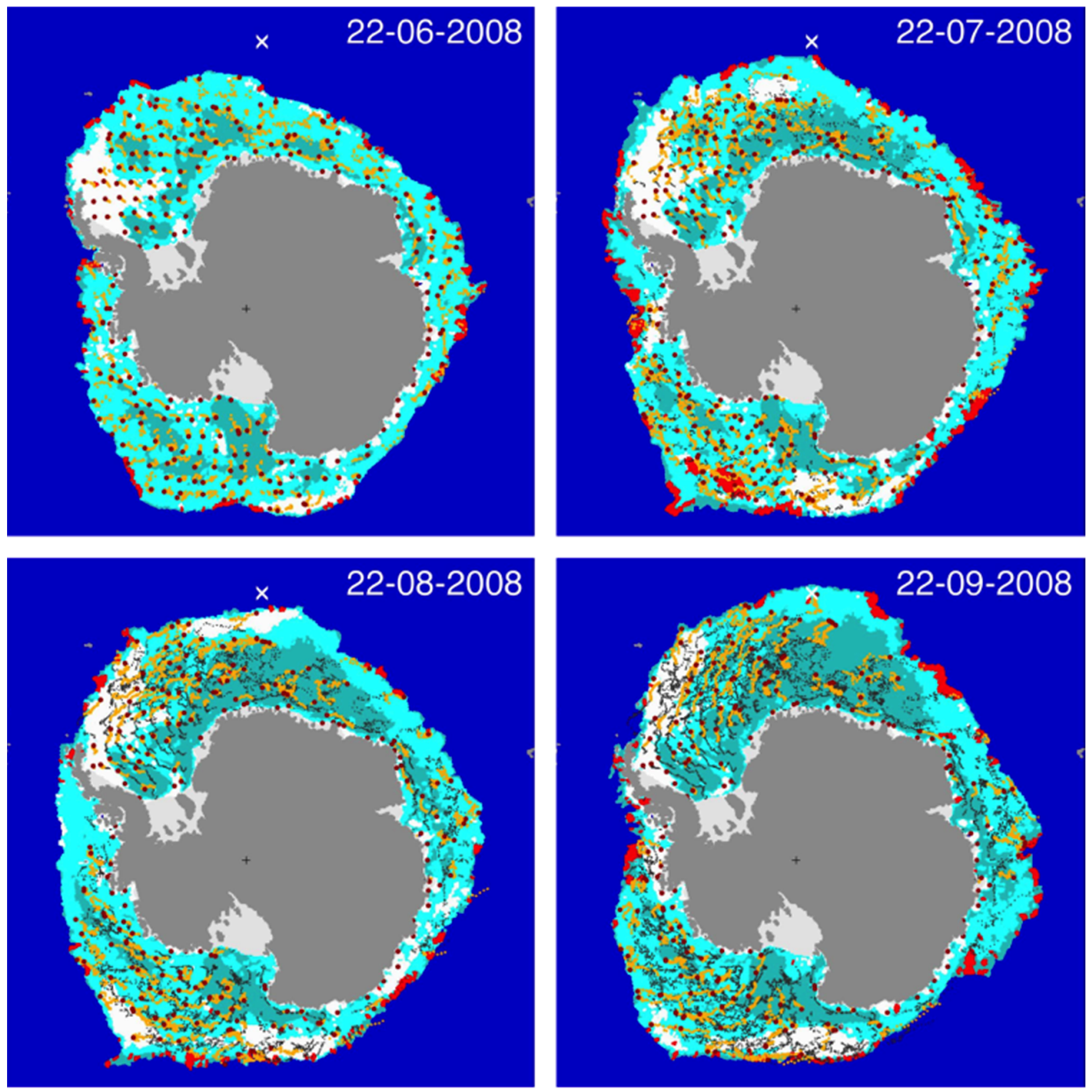

Fig. 5. Antarctic sea ice trajectories overlaid on maps of synoptic sea ice classes on 22 June, July, August, and September 2008. Red dots are the current positions of the trajectories on the given date with the orange trails indicating the drift of the tracks during the past 30 days and the trails consisting of small black dots completing all tracking points along the sea ice tracks since 1 June 2008. The color code for open water and sea ice classification is the same as in Figure 4. Dark grey represents land. The location of Bouvet Island is marked with the white cross.

287 seas, the older sea ice moved outward, driven by katabatic winds that created open space behind

288 the FIZ for YI to grow (see Movie 1). However, the sea ice edge was the closest to the Antarctic

289 coastline in the D’Urville Sea to Mawson Sea region. 
By 22 July (top right, Fig. 5), the FIZ advanced farther north in the South Atlantic toward

291 Bouvet Island with the internal YI expanding to a larger region behind a more distinctive FIZ

292 from the Weddell Sea through the Lazarev Sea to the Riiser-Larsen Sea. Sea ice trajectories

293 adjacent to the coast along the Lazarev and Riiser-Larsen Seas showed a westward drift driven

294 by the polar easterlies. As sea ice moved outward in the Weddell and Lazarev Seas, the ice

295 trajectories curved eastward as driven by the westerlies. In the Ross Sea, the sea ice edge could

296 only reach slightly northward while the region of YI in the internal ice pack was maintained by

297 sustaining winds off the Ross Ice Shelf. In this region, sea ice trajectories revealed a split

298 eastward and westward as sea ice moved outward away from the shoreline (Movie 1). From the

299 D'Urville Sea to Mawson Sea, the ice edge was stable and did not extend much farther after June

300 with some motions corresponding to the easterlies along the coast. Several small areas of 301 transient ice surface melt occurred along the ice edge and within FIZ (top right, Fig. 5).

302 By August (lower left panel, Fig. 5), the region of internal YI in the Weddell Sea through 303 Lazarev Sea to Riiser-Larsen Sea had grown larger. The inner side of the FIZ was also pushed 304 outward while the outer side had not advanced or even slightly retreated in the Weddell Sea, 305 resulting in a smaller FIZ width. Sea ice trajectories tracked from June to August clearly show 306 the cyclonic pattern of the Weddell Gyre formed by the Antarctic Circumpolar Current (ACC) 307 interactions with the Antarctic Continental Shelf. The internal YI also appeared larger in 308 Cooperation Sea behind the FIZ. In the Ross Sea, the internal YI was persistent while sea ice 309 trajectories off the Ross Ice Shelf exhibited the westward and eastward split (also see Movie 1).

310 The pattern of the Ross Sea gyre became well defined by the long June-August trajectories of sea

311 ice as the outer OI and RI arched and followed along the westerlies (Movie 1). Again sea ice in 
312 the D'Urville Sea to the Mawson Sea region remained stable, although with transient melt areas

313 occurred on the sea ice surface near the ice edge.

314 By September (lower right, Fig. 5), the internal YI extent became the largest as the inner side

315 of the FIZ advanced northward across the Weddell, Lazarev, Riiser-Larsen, and Cosmonaut

316 Seas, while the trajectories of OI and RI in the FIZ traced along consistently with the westerlies.

317 At this time, the outer side of the FIZ reached Bouvet Island. In the Ross Sea, the internal YI

318 extent became larger compared to that in earlier months while the outer sea ice in the FIZ

319 continued to be entrained by the westerlies (Movie 1). The extent of the internal YI in the

320 Cooperation and Davis Seas also widened. The sea ice edge retreated in the D'Urville Sea while

321 it extended in the adjacent Mawson Sea. Between June and September, SIE in the

322 Bellingshausen Sea was variable with intermittent retreats and advances while transient melt

323 areas on the sea ice surface were observed in different months (Fig. 5). In late September, the

324 FIZ was still persistently surrounding and protecting the internal sea ice around Antarctica while

325 sea ice in the FIZ was consistently recirculated by the westerlies (Movie 1). In an opposite

326 manner, winds in the Arctic can significantly contribute to sea ice loss such as the 'Polar

327 Express' driven by the dipole pattern of atmospheric anomalies (Nghiem et al., 2007; Perovich et

328 al., 2011), which accelerates sea ice transport directly out of Fram Strait in the Arctic.

329 7. Factors Influencing the Formation and Evolution of Sea Ice

330 Given the new insights derived from the above observations of sea ice trajectories and 331 synoptic classes, next we discuss factors that enhance the growth and persistently maintain the

332 Antarctic sea ice cover. First, regarding the physical characteristics of sea ice itself, the FIZ

333 consisting of older and thicker sea ice with more snow accumulation adjacent to the sea ice edge

334 constitutes an opposite condition to what is typically found in the Arctic where the peripheral 
335 marginal ice zone (MIZ) mostly consists of younger, thinner, and smoother level first-year sea

336 ice with less snow (except in Greenland Sea) including unconsolidated pancake, nilas, and new

337 ice like frazil and grease ice (WMO, 2014), easily broken up by wind-wave actions and melted

338 from surface by warm air or from beneath by warm waters (Perovich et al., 2015, Webster et al.,

3392014,2015 ) and sensitive to dynamic or thermodynamic forcing that reduces sea ice in the Arctic

340 (Perovich, 2011). Moreover, the older and thicker sea ice in the Antarctic FIZ, extending $100 \mathrm{~km}$

341 to $1000 \mathrm{~km}$ (Section 5) around the ice pack, can suppress sea states more effectively and thus

342 reduce sea ice break-up induced by storms as compared to feeble ice conditions in the Arctic

343 MIZ.

344 In the internal sea ice region behind the FIZ, persistent katabatic winds force the opening,

345 production, and advection of ice. In the newly opened or ice divergence areas, protected behind

346 the FIZ, the YI can have a large growth rate, inversely related to sea ice thickness by as much as

347 an order of magnitude between thin and thick ice (Thorndike et al., 1975). Sea ice production is

348 thus enhanced as winds keep refreshing the effective growth of the pack with fast-growing new

349 ice (Heil et al., 1998). In leads and polynyas opened by persistent winds, ice production is so

350 effective that these areas are considered as ice factories (Barber and Massom, 2007), which

351 amply supply sea ice and thus contribute to sustaining the Antarctic sea ice cover. As the internal

352 ice is forced to converge toward the inner side of the formidable FIZ, ice ridging is enhanced and

353 ice volume can increase dynamically by ice convergence as suggested by Zhang (2013). Field

354 observations in the Bellingshausen and Amundsen Seas indicate that rafting and ridging play

355 important roles at different stages of sea ice floe development in the process of floe thickening

356 (Worby et al., 1996). 
The general pattern of persistent offshore winds that drive the FIZ outward (Movie 1) is also

358 effective in promoting sea ice growth by the advection of very cold air to grow more ice, by the

359 forcing to advance the sea ice edge outward, and by the suppression of waves due to the ice

360 advancing and thus impeding water mixing and subsurface melt (Nghiem et al., 2012). Offshore

361 winds blowing across the sea ice surface are also less effective in creating large waves, and thus

362 resulting a calm sea state (Nghiem et al., 2012). When on-ice winds occur, sea ice near the edge

363 can become compacted (Massom et al., 2008), thereby reinforcing the FIZ. Furthermore, such

364 compaction promotes the jet formation (Heorton et al., 2014) that sustains the recirculation of sea

365 ice in the FIZ.

366 Winds such as the polar westerlies, easterlies, and offshore katabatic winds play a major role

367 in forcing sea ice growth and dynamics as presented above. The pattern of wind fields around

368 Antarctica is consistently controlled and shaped by the Antarctic topography, including the

369 coastal morphology and the presence of the ice sheet and associated ice shelves. Parish and

370 Cassano (2003) found that Antarctic surface winds display a high degree of persistence with

371 mean directions related to the local topographic configuration of the ice sheet. In their flow

372 simulation, the initial arbitrary circumpolar low-level winds become modified by the Antarctic

373 terrain within 72 hours such that the direction of the wind vectors becomes tied to the underlying

374 terrain. Results from this simulation and from later analyses (Parish et al., 2006) even hint at the

375 westward and eastward split off the Ross Ice Shelf, which is evident in sea ice drift trajectories

376 observed with satellite data (see the region of sea ice at 6 o'clock in Movie 1). Parish and

377 Cassano (2003) further suggest that the establishment of the low-level wintertime Antarctic wind

378 field is critically dependent on the role of topography in shaping the Antarctic boundary layer

379 winds through blocking and subsequent adjustment. 

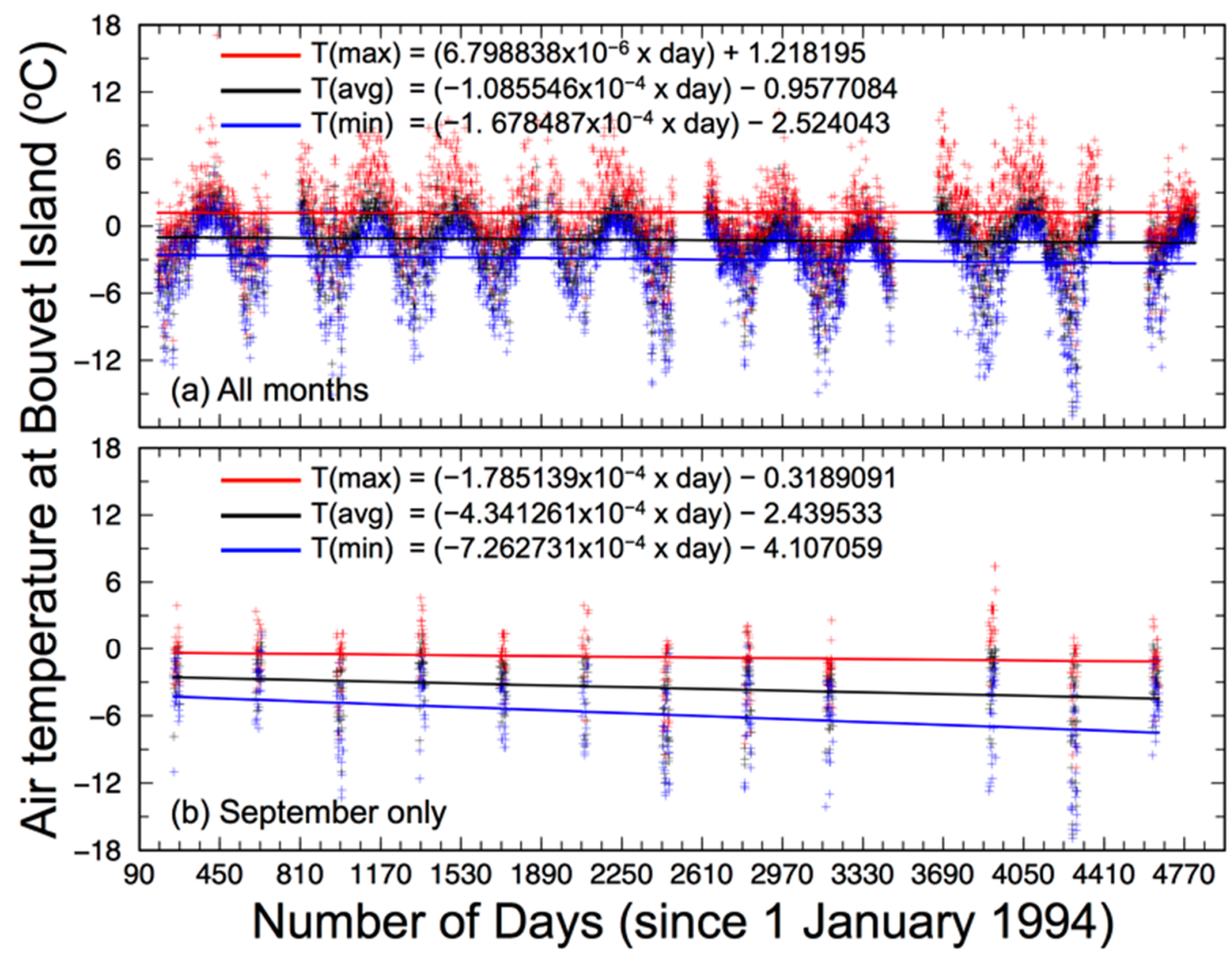

Fig. 6. Air temperature measured at Bouvet Island, obtained from the National Oceanic and Atmospheric Administration (NOAA) Global Surface Summary of the Day (GSOD) dataset (https://data.noaa.gov/dataset/global-surface-summary-of-the-day-gsod). The horizontal axis is for number of days counted from 1 January 1994 (1 is for 1 January 1994, 366 is for 1 January 1995 , etc.). This uninhabited island is located near a triple junction on the southern end of the Mid-Atlantic Ridge. It is the most remote island in the world with more than 1,600 km away from the nearest land in any direction.

During the growth season, Antarctic sea ice reaches north up to an oceanic frontal zone,

382 where SIE cannot advance much farther and seems to be constrained to certain locations in

383 various regions of the Southern Ocean (Movie 1). Throughout the decade of 1999-2009, the SIE

384 attained its maxima at or near Bouvet Island around the September equinox (Fig. 4), except in

3852001 and 2006 when SIE also expanded to the island but later in October. Over an extensive

386 region in the Southern Ocean from north of Bouvet Island to the Antarctic coast, more than

38711,000 conductivity-temperature-depth profiles, collected by sensors mounted on southern 
389 Regime to the Weddell Cold Regime across Bouvet Island (Biuw et al., 2010; Zhou, 2013). This

390 oceanic frontal pattern of warm and cold waters, spanning across Bouvet Island, continues

391 delimiting the northern extent of the Antarctic sea ice cover in the South Atlantic Ocean, as sea

392 ice cannot survive when it reaches the warm waters. Moreover, air temperatures measured at

393 Bouvet Island have been stable over a period of 13 years since 1994 (Fig. 6), which is another

394 factor supporting the sea ice stability in this region.

395 To examine patterns of SST around SIE, the Multi-sensor Ultra-high Resolution (MUR) SST

396 product was obtained from the Physical Oceanography Distributed Active Archive Center

397 (MUR, 2010), which has a relative accuracy of $0.5^{\circ} \mathrm{C}$ in high-latitude oceans. As examples,

398 MUR SST for 2008 and 2009 are overlaid on SIE around September equinox (Fig. 7). The

399 results reveal that SIE closely conforms to the isotherm at $-1.4^{\circ} \mathrm{C}$, slightly above a seawater
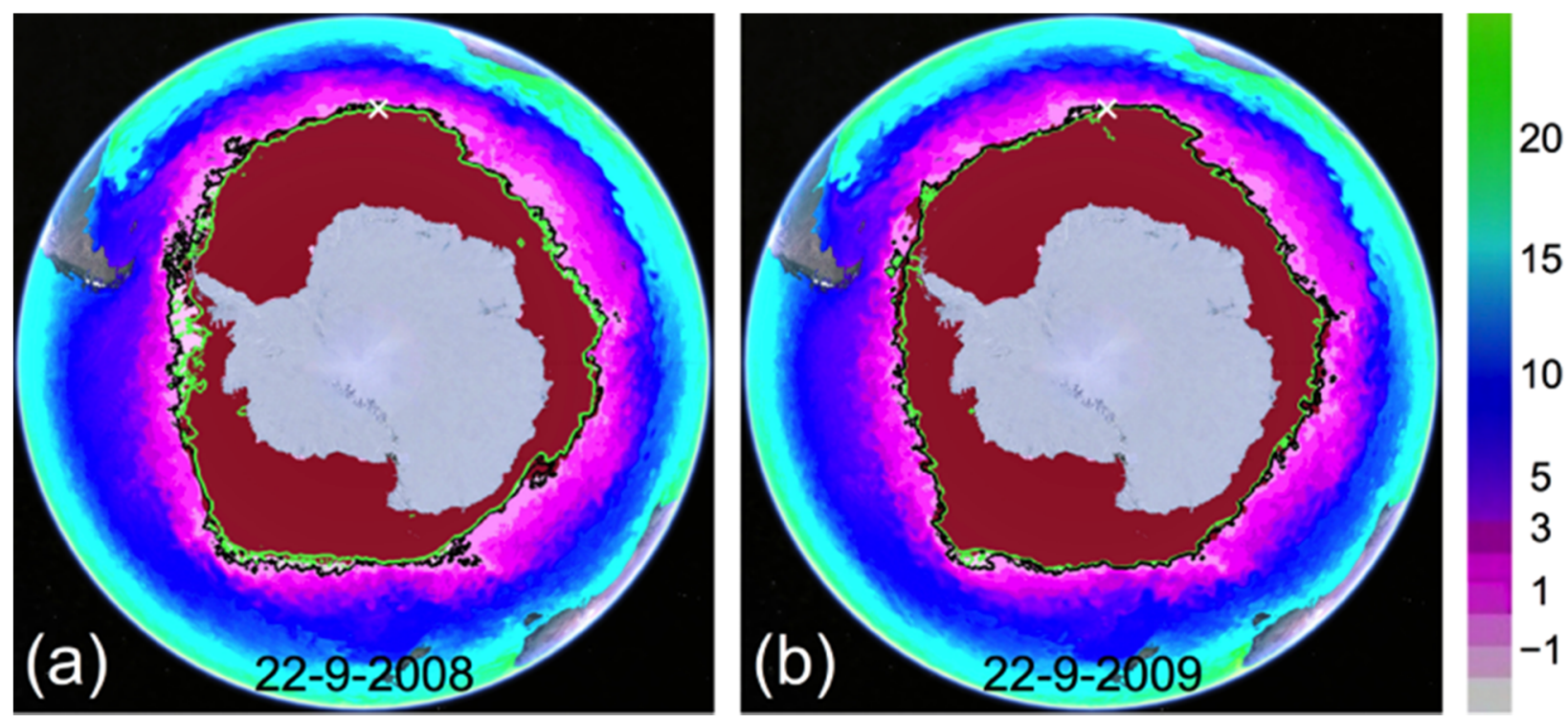

Fig. 7. Maps of Multi-sensor Ultra-high Resolution (MUR) Sea Surface Temperature (SST) represented by the color bar in degrees Celsius on the right with isotherms at $-1.0^{\circ} \mathrm{C}$ (black contour) and $-1.4^{\circ} \mathrm{C}$ (green contour) on National Ice Center (NIC) Sea Ice Extent (SIE) mask in maroon for: (a) 22 September 2008, and (b) 22 September 2009. The white cross marks the location of Bouvet Island. 
400 freezing point around $-1.9^{\circ} \mathrm{C}$ (Foldvik and Kvinge, 1974). The SST isotherm at $-1.0^{\circ} \mathrm{C}$ is also

401 relatively close to the ice edge in most places, although it may have some detachment from the

402 SIE in some cases such as in the Bellingshausen Sea in 2008 (Fig. 7). In general, the SIE is

403 typically enclosed by the $-1.0^{\circ} \mathrm{C} \mathrm{SST}$ isotherm in each year.

404 The overall conformance of SIE to the SST isotherms indicate that ocean temperatures exert

405 significant control in delimiting the maximum reach of SIE. In turn, patterns of warm and cold

406 waters associated with oceanic fronts are significantly governed by bathymetry (Orsi et al., 1995;

407 Moore et al., 1997; Langlais et al., 2011; Kim and Orsi, 2014). In particular, Kim and Orsi used

408 buoy, hydrographic, and altimetric data to infer ACC fronts and their variability between 1992-

409 2011, which encompasses the entire period (1999-2009) considered in this study.

410 In the Southern Ocean, the locations of $-1.0^{\circ} \mathrm{C}$ SST isotherms on 22 September in 1999-2009

411 are closely bundled, especially around the region of Bouvet Island and the meridionally

412 conjugate region $\left(180^{\circ}\right.$ away in longitude) on the opposite side of the continent (Fig. 8). These

413 isotherms are in the proximity of the southern ACC front, or sACCf, delineated by Kim and Orsi

414 (2014) (Fig. 8) and by others (Orsi et al., 1995; Sokolov and Rintoul, 2009). Pronounced

415 seafloor features can strongly guide sACCf, such as in the region around Bouvet Island, located

416 at a triple junction of the American-Antarctic, Mid-Atlantic, and Atlantic-Indian Ridges, and in

417 the region of Pacific-Antarctic Ridge in the Somov Sea.

418 Notably, the $-1.0^{\circ} \mathrm{C}$ SST isotherms cut across the Kerguelen Plateau (Fig. 9) through the

419 Fawn Trough where sACCf transports in conformity with the bathymetry (Park et al., 2009).

420 This is also where the seasonal maximum SIE can recurrently reach to, but cannot cross over to

421 the warm side. While effects of Antarctic bathymetry may contribute to the overall stability of 


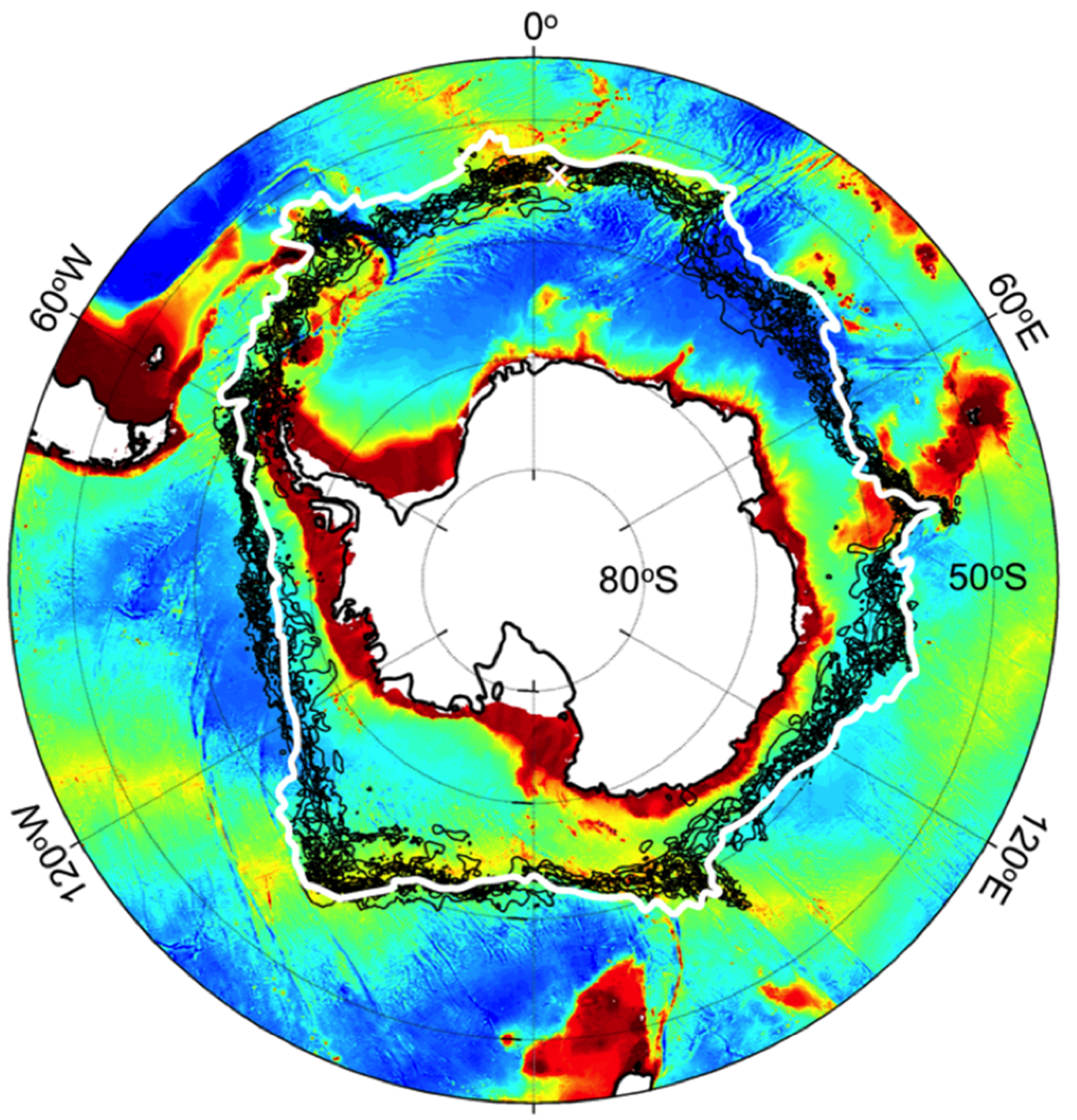

\section{$\begin{array}{llllll}6000 & 5000 & 4000 & 3000 & 2000 & 1000\end{array}$ Depth from GEBCO-2014 Bathymetry (m)}

Fig. 8. Map of the southern Antarctic Circumpolar Current (ACC) front (sACCf) delineated by the white contour (Kim and Orsi, 2014) with MUR SST $-1.0^{\circ} \mathrm{C}$ isotherms represented by the black contours on 22 September in 2002-2009 plotted together with the GEBCO-2014 bathymetry. The isotherms are closely bundled close to the sACCf over pronounced seafloor features such as ridges while they tend to spread apart across smooth abyssal plains. The white cross marks the location of Bouvet Island. 
423 Antarctic sea ice, bathymetry in the Arctic in contrast may work to reduce sea ice more

424 effectively. For example, the landfast sea ice recurrently controlled by the seafloor across the

425 mouth of the Mackenzie River may delay the river discharge to accumulate a larger volume of

426 warmer waters later breaking through the landfast ice to melt more sea ice (Nghiem et al., 2014).

427 Climate-ocean models also indicate that oceanic fronts are tightly constrained by the local

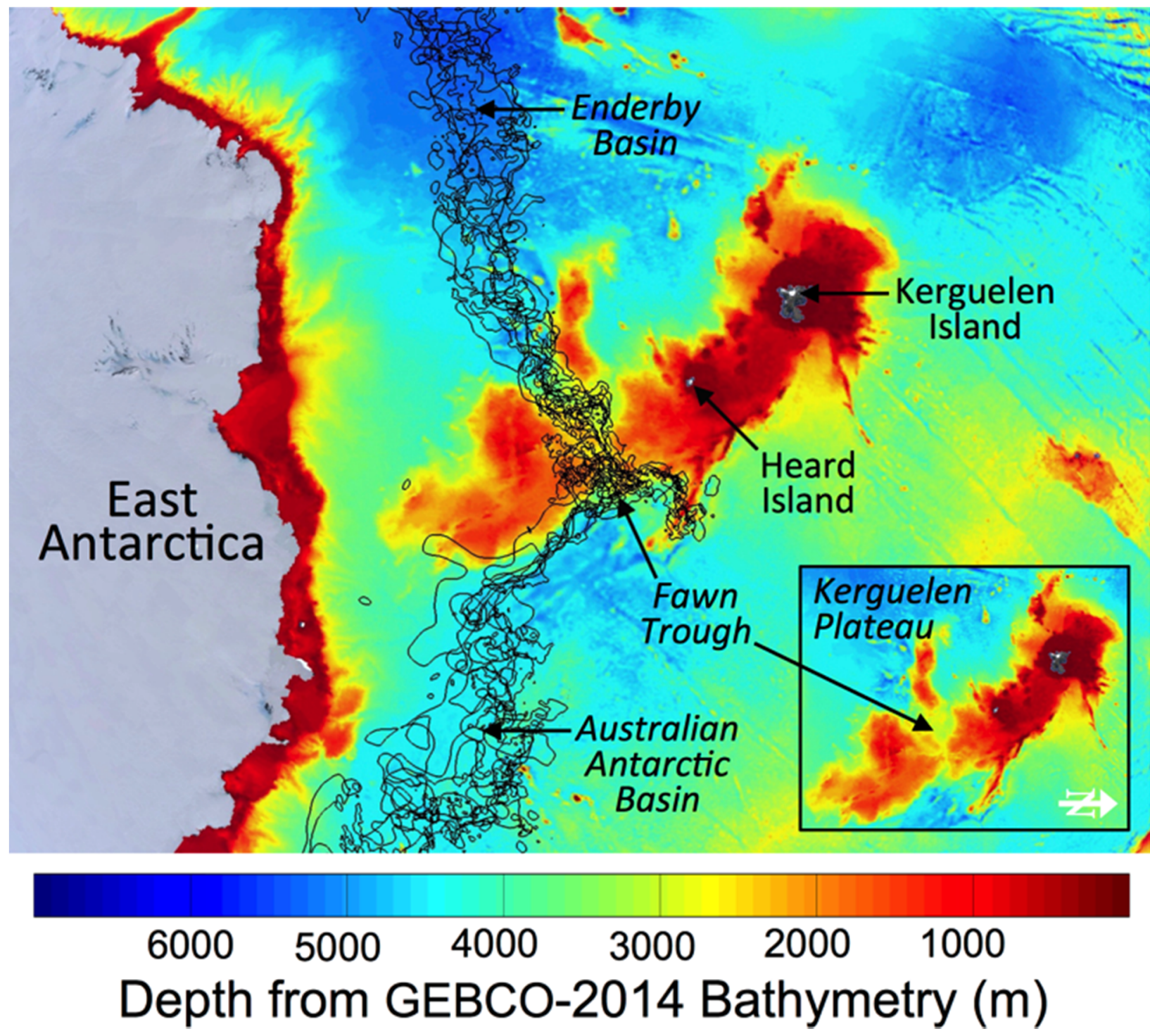

Fig. 9. Map of MUR SST $-1.0^{\circ} \mathrm{C}$ isotherms as black contours on 22 September in 2002-2009 on the GEBCO-2014 bathymetry in the region of the Kerguelen Plateau, a submerged microcontinent. The isotherms closely bundle as they pass across the Kerguelen Plateau through the Fawn Trough. However, the isotherms tend to spread apart over the deep Enderby Basin and the deep Australian Antarctic Basin where seafloor features are not pronounced. 
428 bathymetry (Graham et al., 2012; de Boer et al., 2013), while Coupled Model Intercomparison

429 Project phase 5 (CMIP5) simulations report no significant relationship between the latitudinal

430 positions of the ACC fronts and the westerlies (Meijers et al., 2012). However, the bathymetry

431 may impose less control on the sACCf over the abyssal plains and in deep basins, thereby

432 allowing more effects from atmospheric drivers like SAM and El Niño Southern Oscillation

433 (Kim and Orsi, 2014). These dynamic atmospheric effects can cause more sea ice variability,

434 particularly over the Bellingshausen Plain that is a deep basin (Fig. 8, also see Fig. 1 for the

435 location of the Bellingshausen Plain). The different levels of bathymetry control on SST are

436 also observed over the Kerguelen Plateau, a submerged microcontinent (Fig. 9) also called by

437 paleogeologists and geographers as a submerged continent (Edmond, 2013; World Heritage

438 Encyclopedia, 2016), as the MUR SST isotherms closely pinch through Fawn Trough while they

439 tend to expand over the abyssal plains in the Enderby and Australian Antarctic Basins.

440 In summary, the stark contrast in geophysical characteristics between the southern and 441 northern polar regions causes different behaviors of Antarctic and Arctic sea ice. Regarding sea

442 ice properties, the Antarctic circumpolar FIZ with older rougher and thicker sea ice acts a Great

443 Shield to protect the younger internal ice, as opposed to the Arctic MIZ with younger and thinner

444 sea ice that is easily broken up and melted away. Regarding atmospheric forcing, persistent

445 Antarctic winds create ice factories, thicken ice by ridging, and recirculate ice to enhance and 446 sustain the sea ice cover, as opposed to Arctic winds contributing to sea ice loss such as the

447 'Polar Express' that efficiently exports sea ice directly to warm ocean where it melts. Regarding 448 oceanic effects, the Antarctic bathymetry guides the distribution of water masses to constrain the 449 location of the sACCf that holds the persistence of the sea ice cover, as opposed the Arctic 
450 bathymetry responsible for mechanisms that aggravate sea ice loss (e.g., release of warm waters

451 from the Mackenzie River).

452 8. Conclusion and Discussions

453 Based on daily observations acquired by the SeaWinds scatterometer aboard QuikSCAT

454 from 1999-2009, we have tracked sea ice trajectories and mapped synoptic sea ice classes (RI,

455 OI, and YI) around Antarctica. Trajectories of sea ice tracked in the 2008 growth season (June-

456 September) illustrate the pattern of Antarctic sea ice growth and dynamics, showing the outward

457 expansion of the FIZ where OI and RI accrues and recirculates along with the polar westerlies.

458 Persistent offshore winds recurrently open internal space for effective ice production behind the

459 extensive FIZ, which serves as the GSZ that in turn protects the internal YI. These mechanisms

460 can enhance sea ice production with a high growth rate in the internal YI together with rafting

461 and ridging behind the FIZ that protects and thus persistently preserves the seasonal sea ice pack

462 in the Southern Ocean.

463 As the Antarctic sea ice cover is sustained under the influence of winds guided by 464 topography and waters guided by bathymetry, the general stability of Antarctic sea ice is 465 maintained by both topographic and bathymetric characteristics as these are stable geological 466 factors. Nevertheless, a large regional variability of the SIE can still occur such as in the 467 Bellingshausen Sea where sea ice can advance, retreat, or melt intermittently because the deep 468 abyssal plain does not exert a strong control on water masses and thus allow variable effects 469 from atmospheric forcing. The thermodynamic and dynamic interplay in the Antarctic sea ice 470 formation and evolution processes is consistent with the regional geophysical characteristics that 471 are in a stark contrast to those in the Arctic, thus the different behaviors of sea ice observed in 472 the polar regions should not be considered a paradox. 
While the synoptic sea ice classes defined in this study use statistics of sea ice backscatter,

474 the specific ranges of physical properties pertaining to various sea ice classes still need to be

475 further determined from multiple satellite active and passive sensors together with field

476 observations (e.g., International Polar Year Antarctic Sea Ice Processes and Climate (ASPeCt) at

477 http://aspect.antarctica.gov.au/ipy), and must be rigorously connected with physical-based

478 scattering and emission physics from the first principles founded by Maxwell's equations.

479 Patterns of sea ice classes and their characteristics and thickness are necessary to assess ice

480 volume in the FIZ and over the ice production regions behind it, using remote sensing (e.g.,

481 interferometry and altimetry) and in-situ networks (e.g., International Programme for Antarctic

482 Buoys at http://www.ipab.aq/). Moreover, autonomous sensors in submerged vehicles (e.g.,

483 Williams et al., 2014) or on drones can avoid thickness bias. This is because surveys by such

484 sensors are not limited to selective thinner ice conditions, usually sought after as accessible

485 routes during icebreaker operations.

486 Satellite data and field observations have been acquired at different times, in different

487 seasons and years, and over different regions of Southern Ocean. However, a well designed

488 mission using aircraft and/or satellite remote sensing in conjunction with surface networks and

489 coordinated field campaigns is still necessary to characterize the FIZ. Such a study needs to

490 include the internal ice production processes and their seasonal evolution in order to

491 quantitatively capture the dynamic and thermodynamic processes at play, and thereby rigorously

492 examine the specific regional behaviors of Antarctic sea ice. More complete and accurate

493 datasets also become available for key parameters such as bathymetry (Weatherall et al., 2015)

494 and topography (Zink and Moirera, 2015). These can help advance the understanding and thus

495 improve models that resolve inconsistencies with observations to capture the true Antarctic sea 
496 ice behavior in sea ice modeling. With these considerations, advanced research remains

497 necessary to explain not only present behavior, but also to be able to forecast the response of the

498 Antarctic sea ice cover to climate change given the geophysical constraints described in this

499 paper.

500 Acknowledgments

501 The research carried out at the Jet Propulsion Laboratory, California Institute of Technology,

502 was supported by the National Aeronautics and Space Administration (NASA) Cryospheric

503 Sciences Program. This research was also carried out in part under the support of the National

504 Oceanic and Atmospheric Administration (NOAA) via a subcontract to the Joint Institute for

505 Regional Earth System Science and Engineering of the University of California at Los Angeles.

506 Rigor is funded by NASA, National Science Foundation, and NOAA. The statements, findings,

507 conclusions, and recommendations in this paper are those of the authors and do not necessarily

508 reflect the views of NOAA or the Department of Commerce. We thank S. Helfrich of NIC for

509 preparing NIC SIE data, L. Kaleschke of the University of Hamburg for helping in the ICDC SIE

510 data access, D. T. Nguyen of JPL for assisting in GEBCO bathymetry representation, and J.

511 Vazquez and T. M. Chin of JPL for the MUR SST data access and documentation. We thank

512 the reviewers, all having positive and constructive comments and suggestions in the review

513 process by Remote Sensing of Environment. In particular, we highly appreciate the excellent

514 and thorough review by Claire Parkinson of the NASA Goddard Space Flight Center.

515 Data sources

516 Data can be found at https://podaac.jpl.nasa.gov/ for QuikSCAT,

517 http://dx.doi.org/10.5067/GHGMR-4FJ01 for sea surface temperature,

518 http://www.natice.noaa.gov/Main_Products.htm for NIC sea ice products, 
http://www.gebco.net/data_and_products/gridded_bathymetry_data/ for GEBCO 2014

520 bathymetry, and https://data.noaa.gov/dataset/global-surface-summary-of-the-day-gsod for air

521 temperature data.

\section{References}

523 Ackley, S. F., \& Sullivan, C. W. (1994). Physical controls on the development and 524 characteristics of Antarctic sea-ice biological communities: A review and synthesis. Deep 525 Sea Research Part 1, 41, 1583-1604, doi:10.1016/0967-0637(94)90062-0.

Barber, D. G., \& Nghiem, S. V. (1999). The Role of Snow on the Thermal Dependence of 527 Microwave Backscatter over Sea Ice. J. Geophys. Res., 104(C11), 25789-25803.

528 Barber, D. G., \& Massom, R. A. (2007). The role of sea ice in Arctic and Antarctic polynyas. Ch.

529 1, pp. 1-54, in Polynyas: Windows to the World, eds. W. O. Smith, Jr. and D. G. Barber, 530 Elsevier Oceanography Series 74, Elsevier, Amsterdam, the Netherlands.

531 Beitsch, A., Kern, S., \& Kaleschke, L. (2015). Comparison of SSM/I and AMSR-E sea ice 532 concentrations with ASPeCt ship observations around Antarctica. IEEE Trans. Geosci. Remote Sens., 53(4), 1985-1996, doi:10.1109/TGRS.2014.2351497.

534 Bintanja, R., van Oldenborgh, G. J., Drijfhout, S. S., Wouters, B., \& Katsman, C. A. (2013). 535 Important role for ocean warming and increased ice-shelf melt in Antarctic sea-ice

537 Biuw, M. et al. (2010). Effects of Hydrographic Variability on the Spatial, Seasonal and Diel 538 Diving Patterns of Southern Elephant Seals in the Eastern Weddell Sea. PLoS ONE, 5(11), 539 e13816, doi:10.1371/journal.pone.0013816.

540 de Boer, A. M., Graham, R. M., Thomas, M. D., \& Kohfeld, K. E. (2013). The control of the 541 Southern Hemisphere westerlies on the position of the Subtropical Front. J. Geophys. Res., $542 \quad 118,5669-5675$, doi:10.1002/jgrc.20407. 
543 Edmond, M. (2013), Zone of the Marvellous: In Search of the Antipodes, 242 pp., Auckland $544 \quad$ University Press, New Zealand.

545 Foldvik, A., \& Kvinge, T. (1974). Conditional instability of sea water at the freezing point. 546 Deep-Sea Res., 21, 169-174, doi:10.1016/0011-7471(74)90056-4.

547 Gagné, M.-È., Gillett, N. P., \& Fyfe, J. C. (2015). Observed and simulated changes in Antarctic 548 sea ice extent over the past 50 years. Geophys. Res. Lett., 42, 90-95, 549 doi:10.1002/2014GL062231.

550 Gillett, N. P., \& Thompson, D. W. J. (2003). Simulation of recent Southern Hemisphere climate $551 \quad$ change. Science, 302(5643), 273-275.

552 Golden, K. M., Cheney, M., Ding, K. H., Fung, A. K., Grenfell, T. C., Isaacson, D., Kong, J. A., 553 Nghiem, S. V., Sylvester, J., \& Winebrenner, D. P. (1998). Forward Electromagnetic 554 Scattering Models for Sea Ice. IEEE Trans. Geosci. Remote Sens., 36(5), 1655-1674.

555 Graham, R. M., Heywood, K. J., Chapman, M. R., \& Stevens, D. P. (2012). Southern Ocean 556 fronts: Controlled by wind or topography? J. Geophys. Res., 117, C08018, 557 doi:10.1029/2012JC007887.

558 Heil, P., Lytle, V. I, \& Allison, I. (1998). Enhanced thermodynamic ice growth by sea-ice 559 deformation. Ann. Glaciol., Ed. Budd, W. F., 27, 433-437.

560 Heorton, H. D. B. S., Feltham, D. L., \& Hunt, J. R. C. (2014). The Response of the Sea Ice Edge 561 to Atmospheric and Oceanic Jet Formation. J. Phys. Oceanogr., 44, 2292-2316, 562 doi:10.1175/JPO-D-13-0184.1

563 Holland, P. R. (2014). The seasonality of Antarctic sea ice trends. Geophys. Res. Lett., 41, 4230564 4237, doi:10.1002/2014GL060172. 
IPCC (2013). Climate Change 2013: The Physical Science Basis. Contribution of Working

566 Group I to the Fifth Assessment Report of the Intergovernmental Panel on Climate Change

567 [Stocker and 9 others (eds.)]. Cambridge University Press, Cambridge, United Kingdom and

568 New York, NY, USA, 1535 pp.

569 Jeffries, M. O., Worby, A. P., Morris, K., \& Weeks, W. F. (1997). Seasonal variations in the

570 properties and structural composition of sea ice and snow cover in the Bellingshausen and

571 Amundsen seas, Antarctica. J. Glac., 43(143), 138-151.

572 Kaleschke, L., et al. (2001). SSM/I sea ice remote sensing for mesoscale ocean-atmosphere

573 interaction analysis. Can. J. Remote Sens., 27(5), 526-537.

574 Kern, S., Kaleschke, L., \& Spreen, G. (2010). Climatology of the Nordic (Irminger, Greenland,

575 Barents, Kara and White/Pechora) Seas ice cover based on $85 \mathrm{GHz}$ satellite microwave radiometry: 1992-2008. Tellus, 62A, 411-434, doi:10.1111/j.1600-0870.2010.00457.x.

577 Kern, S., \& Spreen, G. (2015). Uncertainties in Antarctic sea-ice thickness retrieval from ICESat.

578 Ann. Glaciol., 56(69), 107-119, doi:10.3189/2015AoG69A736.

579 Kim, Y. S., \& Orsi, A. H. (2014). On the Variability of Antarctic Circumpolar Current Fronts 580 Inferred from 1992-2011 Altimetry. J. Phys. Oceanogr., 44, 3054-3071, doi:10.1175/JPO-D$581 \quad 13-0217.1$.

582 Kurtz, N. T., \& Markus, T. (2012). Satellite observations of Antarctic sea ice thickness and 583 volume. J. Geophys. Res., 117, C08025, doi:10.1029/2012JC008141.

584 Langlais, C., Rintoul, S., \& Schiller, A. (2011). Variability and mesoscale activity of the 585 Southern Ocean fronts: Identification of a circumpolar coordinate system, Ocean Modelling. $586 \quad 39,79-96$, doi:10.1016/j.ocemod.2011.04.010. 
587 Lewis, M. J., Tison, J. L., Weissling, B., Delille, B., Ackley, S. F., Brabant, F., \& Xie, H., 588 (2011). Sea ice and snow cover characteristics during the winter-spring transition in the 589 Bellingshausen Sea: An overview of SIMBA 2007. Deep-Sea Res. II, 58(9-10), 1019-1038, $590 \quad$ doi:10.1016/j.dsr2.2010.10.027.

591 Maksym, T., Stammerjohn, S. E., Ackley, S., \& Massom, R. (2012). Antarctic Sea Ice - A Polar 592 Opposite? Oceanography, 25(3), 140-151, doi:10.5670/oceanog.2012.88.

593 Manabe, S., Stouffer, R. J., Spelman, M. J., \& Bryan, K. (1991). Transient Responses of a 594 Coupled Ocean-Atmosphere Model to Gradual Change of Atmospheric CO2. Part I: Annual 595 Mean Response. J. Clim., 4, 785-818.

596 Markus, T., Massom, R., Worby, A., Lytle, V., Kurtz, N., \& Maksym, T. (2011). Freeboard, 597 snow depth and sea-ice roughness in East Antarctica from in situ and multiple satellite data. 598 Ann. Glaciol., 52(57), 242-248.

599 Marshall, G. J. (2003). Trends in the Southern Annular Mode from Observations and Reanalyses. $600 \quad$ J. Clim., 16, 4134-4143.

601 Massom, R. A., et al. (2001). Snow on Antarctic sea ice. Review of Geophysics, 39(3), 413-445, 602 doi:10.1029/2000RG000085.

603 Massom, R. A., et al. (2008). West Antarctic Peninsula sea ice in 2005: Extreme ice compaction 604 and ice edge retreat due to strong anomaly with respect to climate. J. Geophys. Res., 113, 605 C02S20, doi:10.1029/2007JC004239.

606 Massom, R. A., Reid, P., Stammerjohn, S., \& Barreira, S. (2009). Sea ice extent and 607 concentration, Antarctica. Chapter 6 in "State of the Climate in 2008," Bull. Amer. Meteor. 608 Soc., 90(8), S1-S196. 
609

610

611

612

613

614

615

616

617

618

619

620

621

622

623

624

625

626

627

628

629

630

631

Meijers, A. J. S., Shuckburgh, E., Bruneau, N., Sallée, J.-B., Bracegirdle, T. J., \& Wang, Z. (2012). Representation of the Antarctic Circumpolar Current in the CMIP5 climate models and future changes under warming scenarios. J. Geophys. Res., 117, C12008, doi:10.1029/2012JC008412.

Moore, J. K., Abbott, M. R., \& Richman, J. G. (1997). Variability in the location of the Antarctic Polar Front $\left(90^{\circ}-20^{\circ} \mathrm{W}\right)$ from satellite sea surface temperature data. J. Geophys. Res., 102(C13), 27825-27833.

MUR (2010), JPL MUR MEaSUREs Project, GHRSST Level 4 MUR Global Foundation Sea Surface Temperature Analysis. Ver. 2. PO.DAAC, CA, USA, available at http://dx.doi.org/10.5067/GHGMR-4FJ01, accessed 12 February 2015.

Nghiem, S. V., Borgeaud, M., Kong, J. A., \& Shin, R. T. (1990). Polarimetric Remote Sensing of Geophysical Media with Layer Random Medium Model. Progress in Electromagnetics Research, edited by J. A. Kong, Vol. 3, Chap. 1, pp 1-73, Elsevier, New York.

Nghiem, S. V., Kwok, R., Kong, J. A., \& Shin, R. T. (1993). A Model with Ellipsoidal Scatterers for Polarimetric Remote Sensing of Anisotropic Layered Media. Radio Sci., 28(5), 687-703.

Nghiem, S. V., Kwok, R., Yueh, S. H., \& Drinkwater, M. R. (1995). Polarimetric Signatures of Sea Ice, 1, Theoretical Model. J. Geophys. Res., 100(C7), 13665-13679.

Nghiem, S. V., \& Neumann, (2007). Arctic Sea-Ice Monitoring. 2007 McGraw-Hill Yearbook of Science and Technology, 2007, 12-15, McGraw-Hill, New York.

Nghiem, S. V., et al. (2006). Depletion of perennial sea ice in the East Arctic Ocean. Geophys. Res. Lett., 33, L17501, doi:10.1029/2006GL027198.

Nghiem, S. V., et al. (2007). Rapid reduction of Arctic perennial sea ice. Geophys. Res. Lett., 34, L19504, doi:10.1029/2007GL031138. 
632 Nghiem, S. V., Clemente-Colón, P., Rigor, I. G., Hall, D. K., \& Neumann, G. (2012). Seafloor

633 control on sea ice. Deep-Sea Res. II - Topical Studies in Oceanography, 77-80, 52-61, 634 doi:10.1016/j.dsr2.2012.04.004.

635 Nghiem, S. V., Hall, D. K., Rigor, I. G., Li, P., \& Neumann, G. (2014). Effects of Mackenzie 636 River discharge and bathymetry on sea ice in the Beaufort Sea. Geophys. Res. Lett., 41(3), 637 doi:10.1002/2013GL058956.

638 NIC (2015). U.S. National Ice Center and Naval Ice Center sea ice products, available at 639 http://www.natice.noaa.gov/Main_Products.htm, accessed 16 February 2015.

640 Orsi, A. H., Whitworth, T., \& Nowlin, W. D. (1995). On the meridional extent and fronts of the 641 Antarctic Circumpolar Current. Deep-Sea Res., 42, 641-673, doi:10.1016/0967$642 \quad 0637(95) 00021-W$.

643 Ozsoy-Cicek, B., Xie, H., Ackley, S. F., \& Ye, K. (2009). Antarctic summer sea ice 644 concentration and extent: comparison of ODEN 2006 ship observations, satellite passive 645 microwave and NIC sea ice charts. The Cryosphere, 3, 1-9.

646 Parish, T. R., \& Cassano, J. J. (2003). Diagnosis of the Katabatic Wind Influence on the 647 Wintertime Antarctic Surface Wind Field from Numerical Simulations. Monthly Weather $648 \quad$ Rev., $131,1128-1139$.

649 Parish, T. R., Cassano, J. J., \& Seefeldt, M. F. (2006). Characteristics of the Ross Ice Shelf air 650 stream as depicted in Antarctic Mesoscale Prediction System simulations. J. Geophys. Res., $651 \quad 111$, D12109, doi:10.1029/2005JD006185.

652 Park, Y.-H., Vivier, F., Roquet, F., \& Kestenare, E. (2009). Direct observations of the ACC 653 transport across the Kerguelen Plateau. Geophys. Res. Lett., 36, L18603, 654 doi:10.1029/2009GL039617. 
655 Parkinson, C. L. (2014). Global Sea Ice Coverage from Satellite Data: Annual Cycle and 35-Yr 656 Trends. J. Clim., 27(24), 9377-9382, doi:10.1175/JCLI-D-14-00605.1.

657 Perovich, D. K. (2011). The Changing Arctic Sea Ice Cover. Oceanography, 24(3), 162-173, 658 http://dx.doi.org/10.5670/oceanog.2011.68.

659 Perovich, D. K., et al. (2011) Physical feedbacks and forcings, in Snow, Water, Ice and 660 Permafrost in the Arctic (SWIPA): Climate Change and the Cryosphere, Section 9.2, Chapter 661 9, pp. 19-30, Arctic Monitoring and Assessment Programme, Oslo, Norway.

662 Perovich, D. K., \& Richter-Menge, J. A. (2015). Regional variability in sea ice melt in a 663 changing Arctic. Phil. Trans. R. Soc. A., 373(2045), doi:10.1098/rsta.2014.0165.

664 Reid, P., \& Massom, R. A. (2015). Successive Antarctic Sea ice Extent Records during 2012, 665 2013, and 2014. Sidebar 6.3 in "State of the Climate in 2014," Bull. Amer. Meteor. Soc., 666 96(7), S163-S214.

667 Rignot, R., Jacobs, S., Mouginot, J., \& Scheuchl, B. (2013). Ice-Shelf Melting Around 668 Antarctica. Science, 341, 266-270, doi:10.1126/science.1235798.

669 Sigmond, M., \& Fyfe, J. C. (2010). Has the ozone hole contributed to increased Antarctic sea ice 670 extent? Geophys. Res. Lett., 37, L18502, doi:10.1029/2010GL044301.

671 Sokolov, S., \& Rintoul, S. R. (2002). Structure of Southern Ocean fronts at $140^{\circ}$ E. J. Mar. Syst., $672 \quad 37,151-184$, doi:10.1016/S0924-7963(02)00200-2.

673 Son, S.-W., et al. (2010). Impact of stratospheric ozone on Southern Hemisphere circulation 674 change: A multimodel assessment. J. Geophys. Res., 115, D00M07, 675 doi:10.1029/2010JD014271. 
676 Stammerjohn, S., Massom, R., Rind, D., \& Martinson, D. (2012). Regions of rapid sea ice

677 change: An inter-hemispheric seasonal comparison. Geophys. Res. Lett., 39, L06501, 678 doi:10.1029/2012GL050874.

679 SPIN (2015). September Sea Ice Outlook: June Report. Sea Ice Prediction Network, $680 \mathrm{http} / /$ www.arcus.org/sipn/sea-ice-outlook/2015/june, accessed 19 July 2015.

681 Spreen, G., Kaleschke, L., \& Heygster, G. (2008). Sea ice remote sensing using AMSR-E 89682 GHz channels. J. Geophys. Res., 113(C2), 1-14, C02S03, doi:10.1029/2005JC003384.

683 Thorndike, A. S., Rothrock, D. A., Maykut, G. A., \& Colony, R. (1975). Thickness distribution 684 of sea ice. J. Geophys. Res., 80(33), 4501-4513, doi:10.1029/JC080i033p04501.

685 Toyota, T., Massom, R., Tateyama, K., Tamura, T., \& Fraser, A. (2011). Properties of snow 686 overlying the sea ice off East Antarctica in late winter, 2007. Deep Sea Res. II, 58, 1137$687 \quad$ 1148, doi: 10.1016/j.dsr2.2010.12.002.

688 Tsai, W.-Y., Nghiem, S. V., Huddleston, J. N., Spencer, M. W., Stiles, B. W., \& West, R. D. 689 (2000). Polarimetric scatterometry: A promising technique for improving ocean surface wind 690 measurements. IEEE Trans. Geosci. Remote Sens., 38(4), 1903-1921.

691 Walsh, J. E. (2009). A comparison of Arctic and Antarctic climate change, present and future. 692 Antarctic Science, 21(3), 179-188, doi:10.1017/S0954102009001874.

693 Weatherall P., Marks, K. M. Jakobsson, M., Schmitt, T., Tani, S., Arndt, J. E., Rovere, M.,. 694 Chayes, D, Ferrini, V., \& Wigley, R. (2015). A new digital bathymetric model of the world's 695 oceans. Earth and Space Science, 2, doi:10.1002/2015EA000107.

696 Webster, M. A., Rigor, I. G., Nghiem, S. V., Kurtz, N. T., Farrell, S. L., Perovich, D. K., \& 697 Sturm, M. (2014). Interdecadal changes in snow depth on Arctic sea ice. J. Geophys. Res., $698 \quad 119,5395-5406$, doi:10.1002/2014JC009985. 
699 Webster, M. A., Rigor, I. G., Perovich, D. K., Richter-Menge, J. A., Polashenski, C. M., \& Light,

700 B. (2015). Seasonal evolution of melt ponds on Arctic sea ice. J. Geophys. Res., 120(9), $701 \quad$ 5968-5982, doi:10.1002/2015JC011030.

702 Williams, G., et al. (2014). Thick and deformed Antarctic sea ice mapped with autonomous 703 underwater vehicles. Nature Geosci., 8, 61-67, doi:10.1038/ngeo2299.

704 WMO (2014). Sea Ice Nomenclature. WMO No. 259, 5th Session of JCOMM Expert Team on 705 Sea Ice.

706 Worby, A. P., Jeffries, M, O., Weeks, W. F., Morris, K., \& Jaña, R. (1996). The thickness 707 distribution of sea ice and snow cover during late winter in the Bellingshausen and 708 Amundsen Seas, Antarctica. J. Geophys. Res., 101(22), 28441-28455.

709 World Heritage Encyclopedia (2016), http://www.worldheritage.org/articles/Kerguelen_Plateau, $710 \quad$ accessed Mar. 2016.

711 Zhang, J. (2007). Increasing Antarctic Sea Ice under Warming Atmospheric and Oceanic 712 Conditions. J. Clim., 20, 2515-2529, doi:10.1175/JCLI4136.1.

713 Zhang, J. (2013). Modeling the Impact of Wind Intensification on Antarctic Sea Ice Volume. J. 714 Clim., 27, 202-214, doi:10.1175/JCLI-D-12-00139.1.

715 Zhou, Q. (2013). Circulation and Exchanges at High-latitude Ocean Margins: Dynamical Models 716 and Observations from Instrumented Seals. Ph. D. Dissertation, The Arctic University of 717 Norway, Tromsø, available at http://munin.uit.no/handle/10037/5926.

718 Zink, M., \& Moirera, A. (2015). TanDEM-X: A Challenging Radar Mission for Generating a 719 New Earth's Topography. pp. 1-4, in Geomorphology for Geosciences, Publisher Bogucki 720 Wydawnictwo Naukowe, Adam Mickiewicz University in Poznań - Institute of Geoecology 721 and Geoinformation, Poland. 
723 Fig. 1. Names of places on a map of Antarctic land and ocean together with the GEBCO-2014 724 bathymetry (http://www.gebco.net/data_and_products/gridded_bathymetry_data/).

725 Fig. 2. Tracking of trajectories of sea ice parcels over different synoptic sea ice classes (see

726 definitions in Section 4 and color code in Fig. 4). The left panel (a) represents the initial set of 727 points in a $2^{\circ}$ grid on sea ice for 1 June 2008 to track the sea ice parcels associated with this set 728 of points to track their trajectories while no new points are introduced or inserted throughout the 729 tracking process. The right panel (b) shows the trajectories of the sea ice parcels at the end of the 730 tracking on the equinox of 22 September 2008, tracing the entire history of the trajectory of each 731 sea ice parcel from where it started, moved around, reached its final position. Red dots are the 732 current positions of the trajectories on the given date with the orange trails indicating the drift of 733 the tracks during the past 30 days and the trails consisting of small black dots completing all 734 tracking points along the sea ice tracks since 1 June 2008. An animation of the daily sea ice 735 trajectories is presented in Movie 1 at http://urban.jpl.nasa.gov/images/NghiemEtAl-Movie1.avi.

736 Fig. 3. Radar backscatter patterns and transect plots of Antarctic sea ice observations in 2008 by 737 the QuikSCAT satellite scatterometer operated at the Ku-band frequency of $13.4 \mathrm{GHz}$. The top 738 left insets are for QuikSCAT backscatter of sea ice on 22 June and 22 September 2008, where 739 the color scale is for backscatter values, blue for ocean, grey for permanent ice, and brown for 740 land. The backscatter plots are for (a) Transect a along $3.38^{\circ} \mathrm{E}$, (b) Transect $\mathrm{b}$ along $45.0^{\circ} \mathrm{E}$, (c) 741 Transect c along $176.62^{\circ} \mathrm{W}$, (d) Transect $\mathrm{d}$ along $135.0^{\circ} \mathrm{W}$, and (e) Transect e along $30.0^{\circ} \mathrm{W}$. The 742 plot colors are green for June, magenta for July, blue for August, and black for September.

743 Fig. 4. Synoptic classes of Antarctic sea ice around the September equinox in 1999-2009. The 744 location of Bouvet Island is marked with the white cross. 
745 Fig. 5. Antarctic sea ice trajectories overlaid on maps of synoptic sea ice classes on 22 June, 746 July, August, and September 2008. Red dots are the current positions of the trajectories on the

747 given date with the orange trails indicating the drift of the tracks during the past 30 days and the 748 trails consisting of small black dots completing all tracking points along the sea ice tracks since 1 749 June 2008. The color code for open water and sea ice classification is the same as in Figure 4. 750 Dark grey represents land. The location of Bouvet Island is marked with the white cross.

751 Fig. 6. Air temperature measured at Bouvet Island, obtained from the National Oceanic and 752 Atmospheric Administration (NOAA) Global Surface Summary of the Day (GSOD) dataset 753 (https://data.noaa.gov/dataset/global-surface-summary-of-the-day-gsod). The horizontal axis is 754 for number of days counted from 1 January 1994 ( 1 is for 1 January 1994, 366 is for 1 January 755 1995, etc.). This uninhabited island is located near a triple junction on the southern end of the 756 Mid-Atlantic Ridge. It is the most remote island in the world with more than 1,600 km away 757 from the nearest land in any direction.

758 Fig. 7. Maps of Multi-sensor Ultra-high Resolution (MUR) Sea Surface Temperature (SST) 759 represented by the color bar in degrees Celsius on the right with isotherms at $-1.0^{\circ} \mathrm{C}$ (black 760 contour) and $-1.4^{\circ} \mathrm{C}$ (green contour) on National Ice Center (NIC) Sea Ice Extent (SIE) mask in 761 maroon for: (a) 22 September 2008, and (b) 22 September 2009. The white cross marks the 762 location of Bouvet Island.

763 Fig. 8. Map of the southern Antarctic Circumpolar Current (ACC) front (sACCf) delineated by 764 the white contour (Kim and Orsi, 2014) with MUR SST $-1.0^{\circ} \mathrm{C}$ isotherms represented by the 765 black contours on 22 September in 2002-2009 plotted together with the GEBCO-2014 766 bathymetry. The isotherms are closely bundled close to the sACCf over pronounced seafloor 
767 features such as ridges while they tend to spread apart across smooth abyssal plains. The white 768 cross marks the location of Bouvet Island.

769 Fig. 9. Map of MUR SST $-1.0^{\circ} \mathrm{C}$ isotherms as black contours on 22 September in 2002-2009 on

770 the GEBCO-2014 bathymetry in the region of the Kerguelen Plateau, a submerged

771 microcontinent. The isotherms closely bundle as they pass across the Kerguelen Plateau through

772 the Fawn Trough. However, the isotherms tend to spread apart over the deep Enderby Basin and 773 the deep Australian Antarctic Basin where seafloor features are not pronounced.

\section{List of Tables}

776 Table 1. Frontal ice zone (FIZ) distances and widths along different longitudes on 22 July, 22

777 August, and 22 September 2008. The FIZ distance is between the coastline (or the outer edge of 778 Ross ice shelf) and the inner edge of FIZ. The FIZ width is between the inner and outer edges of 779 the FIZ. The uncertainty in the FIZ distance and FIZ width is $\pm 25 \mathrm{~km}$.

\section{List of Movies}

782 Movie 1. Movie of Antarctic sea ice trajectories, derived from QuikSCAT satellite data, overlaid 783 on daily maps of synoptic sea ice classes. An initial set of starting points in a $2^{\circ}$ grid on sea ice

784 for 1 June 2008 is chosen and then tracked until 30 September 2008. Red dots are the current 785 positions of the trajectories on each given date. The orange trails indicating the drift of the tracks 786 during the past 30 days, and the trails consisting of small black dots completing all tracking 787 points along the sea ice tracks since 1 June 2008. The color code for open water and sea ice 
788 classification is the same as in Fig. 4. Dark grey represents land. The location of Bouvet Island 789 is marked with the white cross. 